\title{
Báo cáo biến động ngành Toán học năm 2010-2020
}

Vương Quân Hoàng ${ }^{1,2}$, Lã Việt Phương ${ }^{1,2}$, Nguyễn Thanh Thanh Huyền ${ }^{1,2}$, Hồ Mạnh Toàn ${ }^{1,2}$

${ }^{1}$ Al for Social Data Lab, Vuong \& Associates, 3/161 Thinh Quang, Dong Da District, Hanoi 100000, Vietnam

${ }^{2}$ Centre for Interdisciplinary Social Research, Phenikaa University, Yen Nghia Ward, Ha Dong District, Hanoi 100803, Vietnam

\section{Technical Report No. VIASM-AISDL-21.01}

December 29, 2021

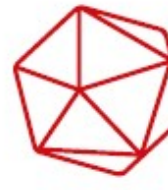

VIASM
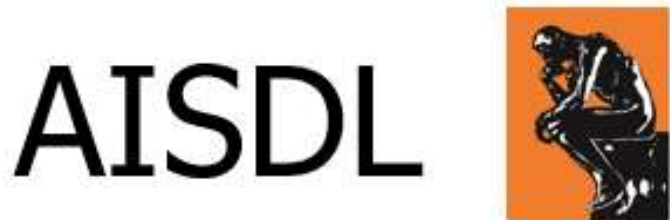

Vietnam Institute for Advanced Study in Mathematics

AI for Social Data Lab 


\section{Giới thiệu chung}

10 năm vừa qua, các cơ quan trung ương, các địa phương đến cơ sở nghiên cứu - đào tạo tại Việt Nam đã chú trọng tạo điều kiện thuận lợi để phát triển toán học. Kết hợp với những thành quả tích luỹ từ giữa thế kỷ $X X$, cộng đồng toán học và những người quan tâm đến toán đang kỳ vọng vào những tiến triển mới về năng suất, chất lượng nghiên cứu tại Việt Nam, và sự mở rộng quan hệ hợp tác nghiên cứu với các nền toán học khác trên thế giới.

Việt Nam có hai chương trình nổi bật ở cấp trung ương là Quỹ Phát triển khoa học và công nghệ Quốc gia NAFOSTED và Chương trình trọng điểm quốc gia phát triển Toán học giai đoạn 2010 đến 2020 (gọi tắt là Chương trình), lần lượt khởi động vào năm 2008 và 2010. Hai chương trình đều đặt bệ phóng cho ngành toán trong giai đoạn 2010-2020, dù có sự khác biệt về đối tượng ngành. Quỹ NAFOSTED nhắm tới tất cả các ngành khoa học, còn Chương trình thì được thiết kế riêng cho ngành toán. Dù vậy, đã có hơn 300 đề tài toán học được quỹ NAFOSTED tài trợ từ năm 2009 đến 2020 (NAFOSTED, n.d.).

Trong khi đó, về Chương trình, một sự kiện quan trọng của nó là cuộc gặp mặt năm 2007 khi Phó Thủ tướng Nguyễn Thiện Nhân chỉ đạo khảo sát tình trạng nghiên cứu Toán học tại Việt Nam, cổ vũ cộng đồng toán học xây dựng chương trình phát triển toán học mới (Lê \& Trần, 2010). Vào ngày 17/ 8/2010, Chương trình đã được Chính phủ chính thức phê duyệt và triển khai vào năm 2011. Mục tiêu chung của Chương trình là phát triển bền vững và toàn diện về nghiên cứu, ứng dụng và giảng dạy toán học, và nâng vị thế nền toán học Việt Nam trong khu vực và thế giới (Thủ tướng Chính phủ, 2010). Về phát triển nghiên cứu, Chương trình có 3 mục tiêu cụ thể: Tăng số lượng và chất lượng công trình công bố quốc tế, xây dựng môi trường nghiên cứu và đào tạo toán học cho người Việt và thu hút các nhà toán học thế giới tới Việt Nam. Tổng kinh phí của Chương trình là 651 tỷ đồng.

Hạt nhân của Chương trình là Viện Nghiên cứu cấp cao về Toán (VIASM) cũng chính thức thành lập và đi vào hoạt động năm 2010. VIASM là nơi tạo điều kiện cho các hoạt động nghiên cứu và đào tạo về Toán cho cán bộ giảng viên toán, nghiên cứu sinh, và các nhà toán học Việt Nam. Được xây dựng dựa trên mô hình Institute for Advanced Study (Viện Nghiên cứu cao cấp IAS - Princeton) và Mathematical Sciences Research Institute (Viện Nghiên cứu toán học MSRI - Berkeley), VIASM nhắm tới mục tiêu trở thành trung tâm toán học xuất sắc để thu hút các nhà khoa học quốc tế tới Việt Nam và là cầu nối cho những nhà toán học trong nước và nước ngoài (Lê \& Trần, 2010). VIASM đang là nơi cộng tác và cố vấn của nhiều giáo sư toán học nổi tiếng thế giới như Lionel Schwartz (Đại học Paris XIII), Phạm Hữu Tiệp (Đại học Rutgers), Phillip Griffiths (Viện Nghiên cứu cao cấp IAS - Princeton). Từ năm 2017 đến nay, VIASM đã chào đón 150 khách mời và nghiên cứu viên làm việc trong thời gian ngắn hạn, và số lượng bài công bố hằng năm khoảng 5 năm gần đây khá đều đặn (khoảng 50 công bố/năm) (VIASM, 2021).

Nguồn tài trợ nghiên cứu của các cơ quan tỉnh/thành phố, trường đại học và doanh nghiệp đã dồi dào hơn trong giai đoạn 2010-2020. Hiện nay, các tỉnh đều tài trợ cho các dự án khoa học và công nghệ. Mức độ ưu tiên đầu tư nghiên cứu toán phụ thuộc vào tính chất và khả năng tài chính của từng tỉnh, nhưng việc tiếp cận nguồn lực kinh tế cho nghiên cứu đã thuận lợi hơn. Các trường đại học hiện cũng tăng đầu tư nâng cao năng lực nghiên cứu của cán bộ, giảng viên, vì khả năng nghiên cứu dần trở thành tiêu chí quan trọng để xếp hạng các trường đại học. Sự tham gia của doanh nghiệp là một điều kiện thuận lợi khác. Hiện nay, có hai quỹ đổi mới sáng tạo doanh nghiệp lớn trong nước là Quỹ Đổi mới sáng tạo của tập đoàn VinGroup và tập đoàn Phenikaa. Quỹ Đổi mới sáng tạo Vingroup (Vingroup Innovation Foundation - VinIF) thuộc Viện Nghiên cứu Dữ liệu lớn của tập đoàn VinGroup (Institute of Big Data - VNCDLL) hiện đang tài trợ các dự án khoa học, ưu tiên ngành dữ liệu lớn (Big Data), trí tuệ nhân tạo (AI), học máy (Machine Learning) (VINIF, n.d.) . Quỹ Đổi mới Sáng tạp của tập đoàn Phenikaa, thành lập năm 2019 với nguồn kinh phí 1000 tỷ đồng, cũng ưu tiên các dự án khoa học có tính đột phá quốc tế (Trường Đại học Phenikaa, 2019). Dù chưa phổ biến, nhưng sự thành lập của các quỹ doanh nghiệp là bước tiến lớn trong thập niên vừa qua. 
Truyền thống 60 năm (kể từ công bố quốc tế đầu tiên của GS Lê Văn Thiêm năm 1947) đã để lại nhiều di sản để ngành toán tận dụng và vươn lên. Di sản thứ nhất là một số cơ sở nghiên cứu toán học có uy tín quốc tế, nổi bật là Viện Toán học (Viện Hàn Lâm Khoa học Công nghệ). Viện là nơi làm việc của nhiều nhà toán học nổi tiếng (Lê Văn Thiêm, Hoàng Tuy., Ngô Việt Trung, Phùng Hồ Hải, ...) và đã đào tạo nhiều thế hệ tiến sĩ. Viện có truyền thống công bố quốc tế lâu đời và đã công bố trên các tạp chí đầu ngành như Mathematical Programming, Duke Mathematical Journal, Advances in Mathematics, Journal für die reine und angewandte Mathematik. Năm 1994, Viện Toán học được Viện Hàn Lâm Khoa học Thế giới Thứ ba công nhận là trung tâm xuất sắc, đưa Việt Nam lên bản đồ toán học quốc tế. Truyền thống này là tấm gương và bệ phóng phát triển có các cơ sở nghiên cứu khác tại Việt Nam. Ngoài ra, Viện Toán học cũng là cơ quan quản lý hai tạp chí toán học quốc tế uy tín là Vietnam Journal of Mathematics và Acta Mathematica Vietnamica.

Thứ hai, thành tựu được thế giới công nhận của một số cá nhân Việt là nguồn động lực cho thế hệ trẻ và các nhà toán học trong nước. Ví dụ, giải thưởng Fields năm 2010 của GS Ngô Bảo Châu giúp Việt Nam trở thành quốc gia châu Á thứ hai sau Nhật Bản nhận được vinh dự trên. Thành công của giáo sư động viên thế hệ trẻ theo đuổi đam mê toán học, củng cố niềm tin vào tương lai toán học Việt (Châu et al., 2020). Ngày 3/3/2010, giáo sư được bổ nhiệm làm giám đốc VIASM (Lê \& Trần, 2010). Ngoài Ngô Bảo Châu, Hoàng Tuy, người được coi là cha đẻ ngành Tối ưu toàn cục (Global Optimization), là nguồn cảm hứng của nhiều nhà nghiên cứu. Những đóng góp lớn lao của Hoàng Tụy cho lĩnh vực Tối ưu toàn cục được Giải thưởng Constantin Carathéodory vinh danh trọn đời.

Như vậy, toán học Việt Nam giai đoạn 2010-2020 có những điều kiện thuận lợi để tạo bước ngoặt mới. Nhằm khảo sát sơ bộ tình hình toán học năm 2010-2020, báo cáo này sử dụng phương pháp định lượng để phân tích dữ liệu từ cơ sở dữ liệu SciMath, một CSDL dành riêng cho các nhà toán học Việt. CSDL SciMath thuộc dự án "Phát triển bộ cơ sở dữ liệu khoa học ngành toán của Việt Nam", được phát triển từ ý tưởng của GS Ngô Bảo Châu và tiến sĩ Vương Quân Hoàng (Trung tâm Nghiên cứu Xã hội Liên ngành, Trường Đại học Phenikaa). Bản báo cáo định lượng này tập trung đến các khía cạnh như năng suất, xu hướng công bố, và mạng lưới hợp tác nghiên cứu. Vì các hạn chế của phương pháp định lượng khi đánh giá chất lượng nghiên cứu, báo cáo chỉ mang tính chất tham khảo, hỗ trợ trong việc xác định nhóm nghiên cứu mạnh, và tác giả trẻ tiềm năng, từ đó định hướng các chương trình phát triển toán cũng như các bộ môn khoa học khác trong tương lai. Dù vậy, dữ liệu về năng suất nghiên cứu, công bố trên các tạp chí quốc tế hàng đầu, mạng lưới hợp tác, ... vẫn cho một bức tranh sơ bộ về toán học Việt Nam 10 năm qua.

\section{Cơ sở dữ liệu SciMath}

Công tác xây dựng hệ thống của dự án "Phát triển bộ cơ sở dữ liệu khoa học ngành toán của Việt Nam" được bắt đầu vào tháng 8/2019. Website nhập liệu (truy cập tại http://SciMath.aisdl.com) được kiểm tra chạy thử vào ngày 16/12/2019. Quá trình nhập liệu chính thức bắt đầu vào ngày 23-12-2019.

Mục tiêu của CSDL SciMath là thu thập các công bố toán học thoả mãn hai điều kiện sau:

1. Có ít nhất một tác giả là người Việt Nam, và từng học tập ở Việt Nam.

2. Được đăng tại các tạp chí, sách, kỷ yếu, ... được chỉ mục hóa bởi MathSciNet, zbMATH, Scopus hoặc ISI.

\subsection{Cấu trúc CSDL SciMath}

SciMath là CSDL trung tâm lưu trữ toàn bộ các thông tin về tác giả, tổ chức nghiên cứu, công bố, tạp chí/nhà xuất bản... theo hai tiêu chí trên. Thông tin được thu thập thủ công từ nhiều nguồn khác nhau như CSDL nghiên cứu (Google Scholar, ZbMath, hay Mathscinet), dữ liệu được đóng góp bởi các nhà khoa học hoặc thu tự động nguồn dữ liệu trực tuyến. Các dữ liệu này được biên tập, làm sạch và nhập vào hệ thống.

Cấu trúc của CSDL SciMath như sau: 
Hình 1. Cấu trúc CSDL SciMath

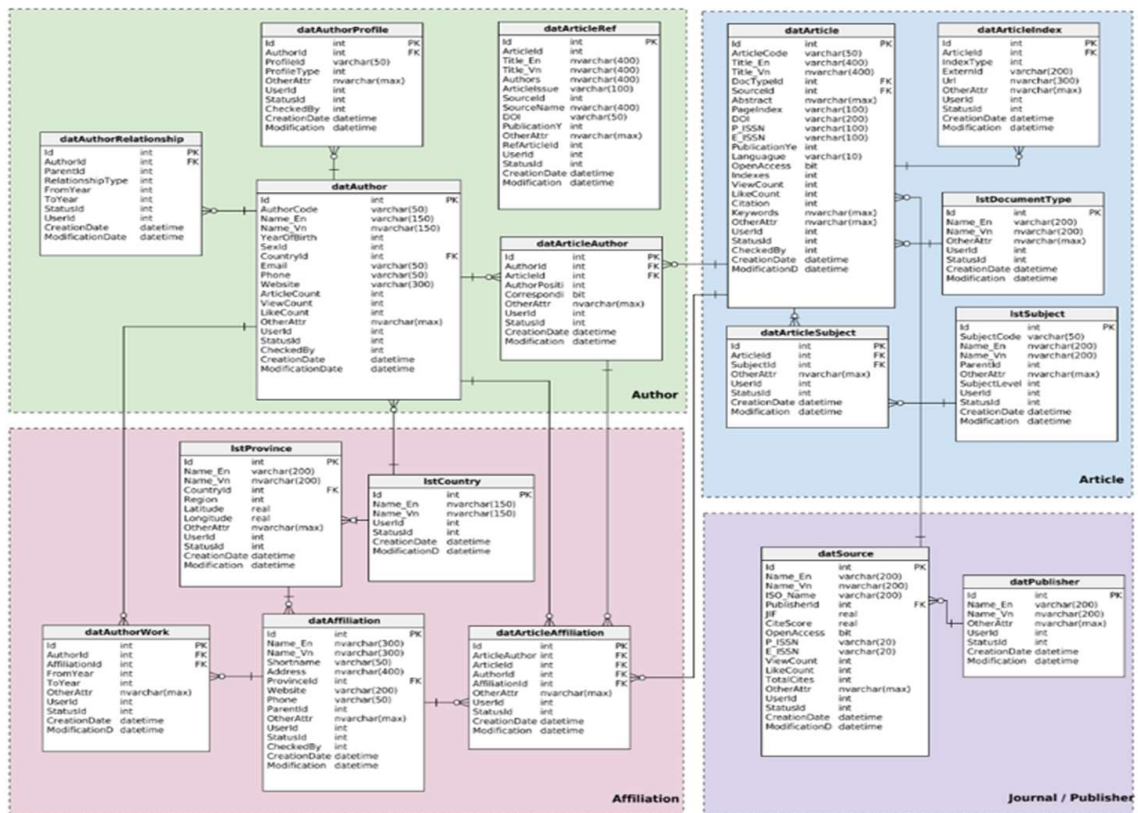

CSDL SciMath có 4 nhóm dữ liệu cơ bản: Article, Author, Affiliation, Source/Publisher. Trong đó, Article là điểm trung tâm để xây dựng, thu thập, và liên kết nhóm dữ liệu khác. Một bài báo được ghi nhận vào CSDL khi và chỉ khi thông tin về Article, Author, và Source đầy đủ. Dưới đây là thông tin cụ thể liên quan đến 4 nhóm dữ liệu:

- $\quad$ Article: dữ liệu bài / nghiên cứu khoa học

Dữ liệu Article sẽ bao gồm các miền sau: tên bài, loại ẩn phẩm (bài báo, sách hoặc bài hội thảo), năm xuất bản, tên tạp chí, DOI/link, Abtract, từ khóa, chuyên ngành, tác giả và cơ quan. Trong đó, tên bài, năm xuất bản, tên tạp chí là các miền bắt buộc điền.

Ngoài ra, dữ liệu bài báo còn ghi lại CSDL (ZbMath, Mathscinet, Web of Science và Scopus) đã chỉ mục bài báo.

- $\quad$ Author: dữ liệu tác giả / nhà nghiên cứu

Dữ liệu tác giả bao gồm các miền sau: Tên tác giả, giới tính, quốc tịch, cơ quan và một số thông tin khác như email, số điện thoại. Mỗi tác giả được ghi nhận tại cơ sở dữ liệu sẽ được gắn một mã nhận diện (ID) dựa trên giới tính, quốc tịch và thứ tự nhập. Ví dụ, tác giả $A$ là người Việt Nam, giới tính nữ do vậy sẽ có mã vf.999 (v: Việt Nam; f: female - nữ). Nếu A là người nước ngoài, giới tính nam sẽ được mã fm.999 (f: foreign - người nước ngoài; m: male - nam). Con số 999 thể hiện đây là tác giả thứ 999 được nhập vào cơ sở dữ liệu.

Các thông tin khác được người thu thập sử dụng làm cơ sở để phân biệt các tác giả trong trường hợp trùng tên hoặc tên viết tắt.

- $\quad$ Affiliation: dữ liệu tổ chức / cơ quan.

Dữ liệu tổ chức / cơ quan của tác giả được lấy theo thông tin tác giả cung cấp ở công bố và ưu tiên lấy đến bậc thứ 2 . Bậc thứ 2 của các trường đại học hoặc việc nghiên cứu lớn như Đại học Quốc gia và Viện Hàn Lâm Khoa học Công nghệ là các trường đại học hoặc việc nghiên cứu trực thuộc như Đại học Khoa học Tự nhiên và Viện Toán học. Với các trường đại học hoặc cơ sở nghiên cứu khác, bậc thứ hai sẽ là các khoa hoặc phòng ban. Ví dụ, bậc thứ hai của trường Đại học Sư phạm Hà Nội là các khoa như Khoa Toán-Tin, Khoa Vật Lý. 
Trong trường hợp bài nghiên cứu không ghi rõ thông tin cơ quan của tác giả, nhân viên thu thập dữ liệu sẽ rà soát hồ sơ của tác giả và lấy cơ sở nghiên cứu tương ứng với thời gian xuất bản nghiên cứu. Trong trường hợp không có đủ thông tin về cơ sở làm việc, mục này sẽ bị bỏ trống.

- $\quad$ Source / Publisher: dữ liệu tạp chí, sách, kỷ yếu và nhà xuất bản

Các tạp chí được ghi nhận vào cơ sở dữ liệu SciMath là các tạp chí được chỉ mục bởi ZbMath, Mathscinet, Web of Science và Scopus.

\subsection{Quy trình nhập liệu}

Bước 1: Thu thập dữ liệu:

- Dữ liệu về các ấn phẩm ngành toán của tác giả Việt Nam được thu thập tự động từ zbMath, Mathscinet và Google Scholar và sau đó được đưa vào cơ sở dữ liệu tham khảo.

- Dữ liệu được nhân viên tìm kiếm từ các ấn phẩm đã xuất bản, trang của các tổ chức, trường, viện nghiên cứu, cv của tác giả.

- Dữ liệu được cung cấp từ các thành viên, chuyên gia của cộng đồng toán học.

Bước 2: Nhập dữ liệu:

- Nhân viên nhập liệu tiến hành kiểm tra và nhập dữ liệu đã thu thập.

- Bổ sung các dữ liệu tác giả, quan hệ cũng như các dữ liệu thuộc tính từ các nguồn khác.

- Hệ thống tự động kiểm tra tính hợp lệ, dữ liệu trùng lặp tác giả, ấn phẩm...

Bước 3: Duyệt dũ̃ liệu:

- Duyệt dữ liệu 2 cấp: cấp 1 duyệt tự động từ dữ liệu đã nhập trước đó, cấp 2 là bước duyệt thủ công dữ liệu cấp 1.

- Thao tác duyệt kiểm tra tính hợp lệ của dữ liệu.

- Kiểm tra các ấn phẩm, tác giả trùng lặp.

- Dữ liệu sau khi duyệt được đưa vào cơ sở dữ liệu SciMath.

- Dù đã có bước tự động kiểm tra của hệ thống, việc duyệt dữ liệu đóng vai trò rất quan trọng để có CSDL chất lượng. Thực hiện kiểm tra 2 lần giúp giảm đi các sai sót khi nhập thủ công như trùng lặp bài, tác giả, ấn phẩm. Quá trình duyệt dữ liệu thủ công này sẽ kiểm tra từng đơn vị dữ liệu liên quan đến bài báo, và tiến hành chỉnh sửa ngay khi xuất hiện các thông tin sai, trùng lặp, hoặc loại bỏ nếu bài không phù hợp với tiêu chí của SciMath. Ví dụ, để tránh các công bố bị lặp do có kí tự toán học, người kiểm tra sẽ tìm kiếm bài báo sử dụng các cụm từ/ chữ cái khác kí hiệu toán học trong tiêu đề bài và tra danh sách bài được hiện trên CSDL. Cách tra cứu và duyệt với các nhóm dữ liệu khác (tạp chí, tác giả, ...) cũng diễn ra tương tự để đảm bảo chất lượng CSDL cao nhất có thể.

Bước 4: Phân tích dữ liệu:

- Các bảng dữ liệu tra cứu, đồ thị được lấy trực tiếp từ cơ sở dữ liệu SciMath phục vụ công tác nghiên cứu.

Quy trình nhập liệu được tóm tắt trong hình vẽ sau:

Hình 2. Quy trình nhập liệu SciMath 


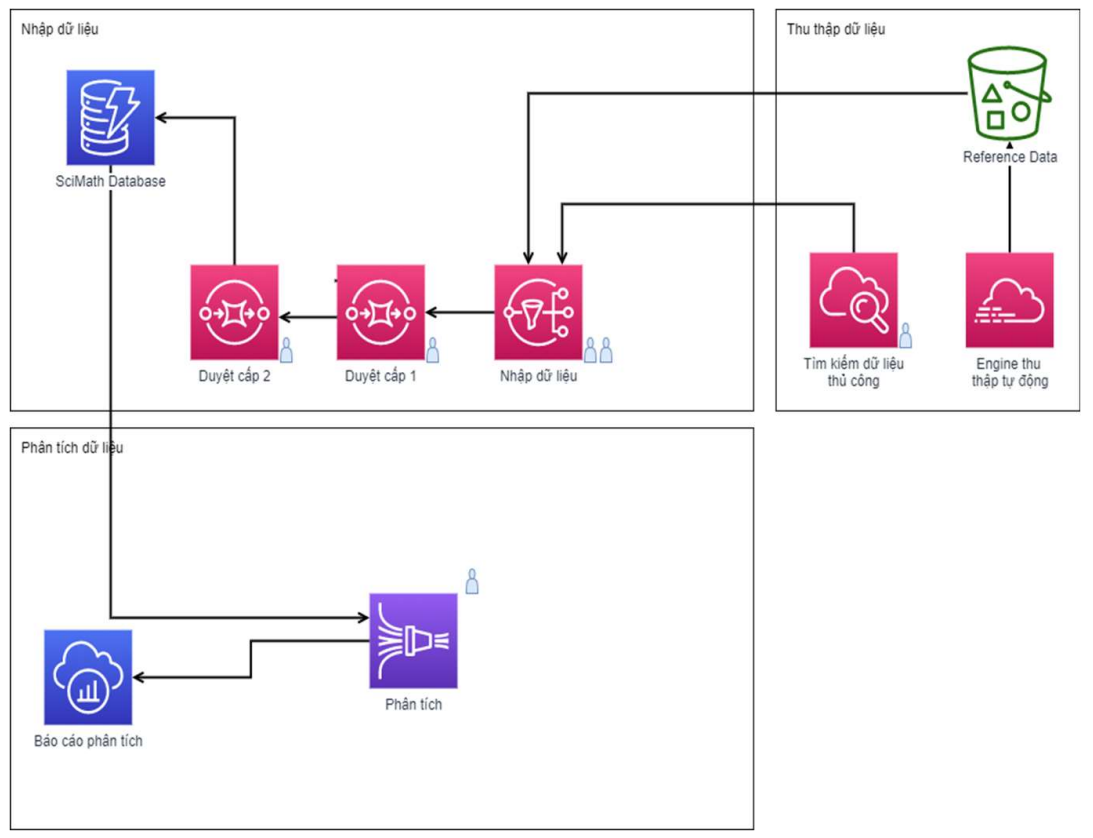

\subsection{Một số điểm mạnh và hạn chế khi sử dụng CSDL SciMath}

CSDL SciMath tổng hợp và lưu trữ thông tin công bố toán học của người Việt từ nhiều CSDL khác, bao gồm MathScinet, ZbMath, Scopus và Web of Science. Vì vậy, SciMath là địa chỉ tốt để người sử dụng truy cập và tìm hiểu được nhiều công bố nhất, từ cấp các cá nhân đến tập thể. Trang thông tin của từng tác giả cung cấp tất cả các thông tin về tạp chí/nhà xuất bản từng công bố, cộng sự (và số lượng nghiên cứu cộng tác), ngành, ... Các dữ liệu này giúp xác định năng suất, xu hướng hợp tác, và các tác giả có công bố trên tạp chí quốc tế hàng đầu. Ngoài ra, các dữ liệu hỗ trợ công tác khảo sát sơ bộ các yếu tố tác động đến năng suất nghiên cứu (ví dụ: tạo nhóm nghiên cứu, hợp tác với tác giả nước ngoài, công tác hoặc học tập tại các cơ sở nghiên cứu uy tín, ...) và các khía cạnh khác.

Vì SciMath ghi chép các thông tin liên quan tới tác giả và nơi công tác, dữ liệu sẽ cho biết các thông tin hữu ích như phân bố giới tính từ cấp quốc gia đến cơ sở, các tác giả người nước ngoài công tác tại Việt Nam. Tuy nhiên, CSDL SciMath chỉ phản ánh được một phần tình trạng người nước ngoài công tác tại Việt Nam, do CSDL chỉ ghi nhận các công bố có người Việt.

Dù đã tận dụng bộ lọc của các CSDL MathScinet, ZbMath, Scopus và Web of Science, SciMath vẫn gặp hạn chế khi đánh giá chất lượng nghiên cứu. Cũng như nhiều CSDL trắc lượng khoa học khác, SciMath có thể "đếm" chính xác số lượng công bố trên tạp chí toán học quốc tế uy tín và được cộng đồng toán học công nhận. Tuy nhiên, quá trình định nghĩa, cập nhật, bổ sung dữ liệu luôn tồn tại những điểm mờ, dẫn tới sự khó khăn đánh giá chính xác chất lượng của từng bài nghiên cứu. Đề bù đắp cho thiếu sót này, hệ thống các cố vấn, chuyên gia là rất cần thiết để CSDL SciMath có thể đảm bảo dữ liệu sạch nhất.

Do vậy, các thông tin mà bản báo cáo (và có thể cả các báo cáo sau này) đưa ra sẽ tồn tại những điểm mờ của dữ liệu. Những thông tin, con số này sẽ tập trung cung cấp cái nhìn tổng quan nhất có thể về năng suất nghiên cứu, xu hướng nghiên cứu và hợp tác nghiên cứu, tình hình công bố tại các tạp chí hàng đầu, tỷ lệ giới tính, ... Những thông tin từ CSDL SciMath, kết hợp cùng với mạng lưới chuyên gia trong ngành Toán học, hy vọng sẽ hỗ trợ các nhà quản lý, các nhà hoạch định chính sách trong quá trình định hướng phát triển Toán học Việt Nam.

\section{Tình hình chung về nghiên cứu toán học giai đoạn 2010-2020:}

\subsection{Về công trình nghiên cứu}


Tính từ công bố đầu tiên vào năm 1947 của GS Lê Văn Thiêm (Thiem, 1947), số lượng công bố quốc tế ngành toán của Việt Nam tăng dần theo thời gian (Hình 3). Giai đoạn 1990-2009 công bố 3,916 nghiên cứu, tương ứng năng suất công bố trung bình một năm là 195.8 nghiên cứu. Năng suất nghiên cứu hằng năm bắt đầu tăng nhanh từ năm 2009. Trạng thái này diễn ra xuyên suốt thời kỳ 2010-2020, đặc biệt là cuối giai đoạn.

Hình 3. Số lượng công bố quốc tế ngành toán từ 1947 đến 2020

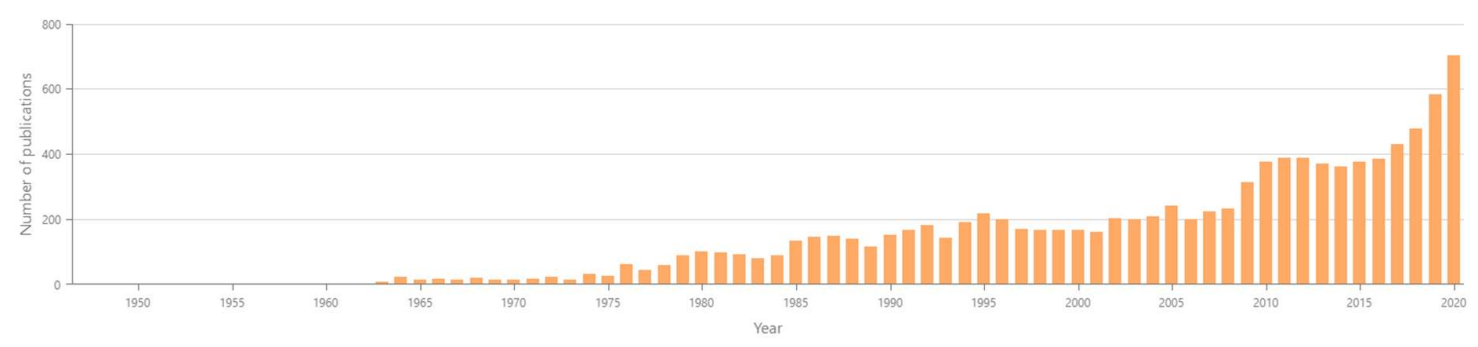

Theo CSDL SciMath, trong giai đoạn 2010-2020 đã có 4857 công bố quốc tế, 2616 tác giả (1439 tác giả Việt Nam), và 1034 cơ quan trong và ngoài nước. Số lượng nghiên cứu trong 6 năm đầu tiên duy trì ở gần 400 công bố các loại. Số lượng nghiên cứu lần đầu tiên vượt qua mức 400 vào năm 2017, và tăng nhanh trong các năm tiếp theo. Năm 2020 ghi nhận số lượng nghiên cứu cao nhất trong lịch sử toán học Việt Nam, 713 công bố (Hình 4).

Hình 4. Số lượng công bố quốc tế ngành toán giai đoạn 2010-2020

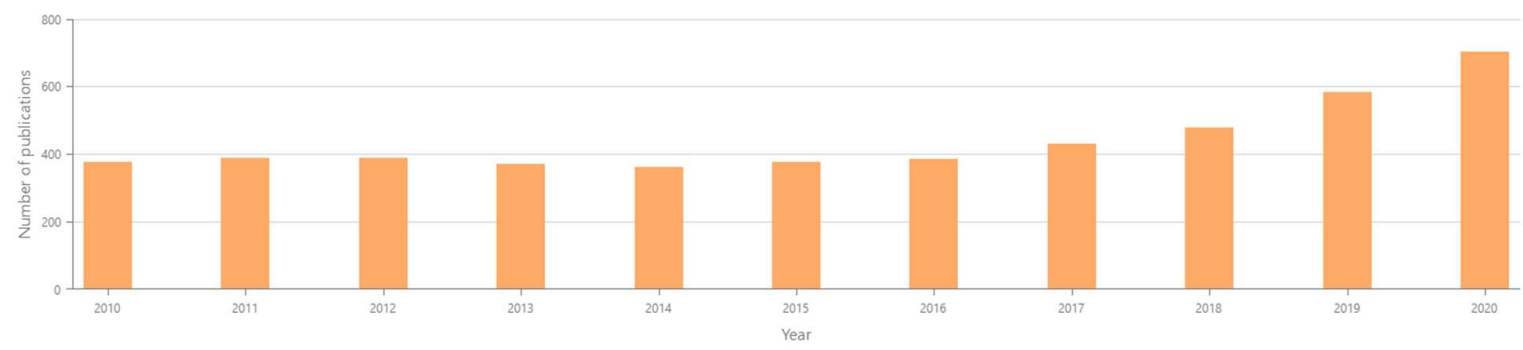

Sự tăng trưởng về nghiên cứu trên tạp chí là động lực chính thúc đẩy năng suất cao hơn (Hình 5). Diễn biến tăng trưởng số lượng công bố chung tương đối trùng khớp với diễn biến của bài báo khoa học. Sách/chương sách (Hình 6) và kỷ yếu (Hình 7) chiếm tỷ trọng không đáng kể trong tổng số công bố hàng năm (khoảng 20 đơn vị/năm mỗi loại). Một khả năng dẫn tới số lượng hạn chế của sách/chương sách và kỷ yếu là quá trình chỉ mục hóa hai loại ấn phẩm này trên các CSDL lớn thường dài hơn so với bài báo khoa học.

Số lượng bài báo khoa học hàng năm tăng nhẹ nhưng không đáng kể trong giai đoạn 1990-2009, chủ yếu giữ mức gần 200 bài/năm (Hình 5). Trong khi đó, số lượng hàng năm trong giai đoạn 2010-2016 là gần 400 công bố. Chỉ số này vượt mức 400 vào 2017 và bắt đầu tăng đột biến trong ba năm tiếp theo. Năm 2020, các nhà toán học người Việt công bố tổng cộng 701 bài báo khoa học.

Hình 5. Số lượng công bố trên tạp chí ngành toán từ 1947 đến 2020 


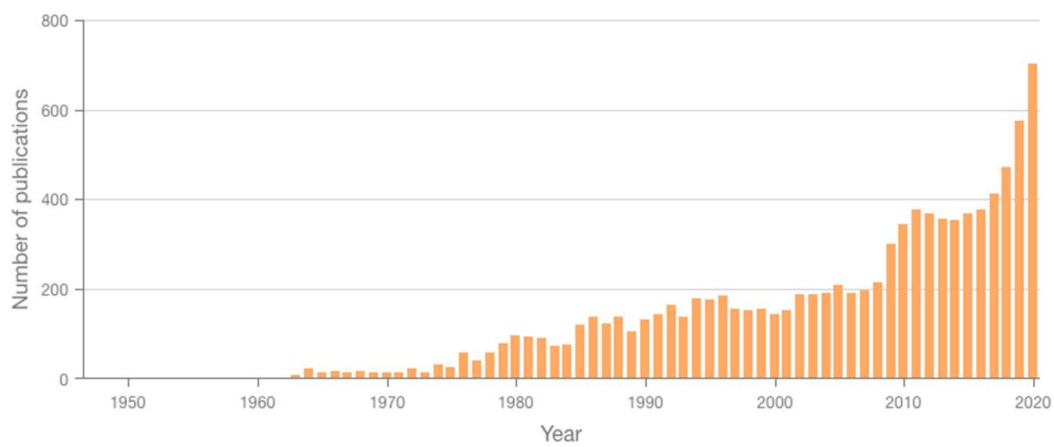

Theo CSDL SciMath, nền toán học Việt Nam đã xuất bản 229 cuốn/chương sách, trong đó 71 đơn vị được phát hành trong giai đoạn 2010-2020 (tương ứng 31\%). Tuy nhiên, số lượng ấn phẩm này hàng năm không ổn định. Ngoài 7 năm tăng đột biến (có trên 10 cuốn/chương sách), hàng năm người Việt xuất bản khoảng 5 cuốn/chương sách.

Hình 6. Số lượng sách và chương sách ngành toán từ 1947 đến 2020

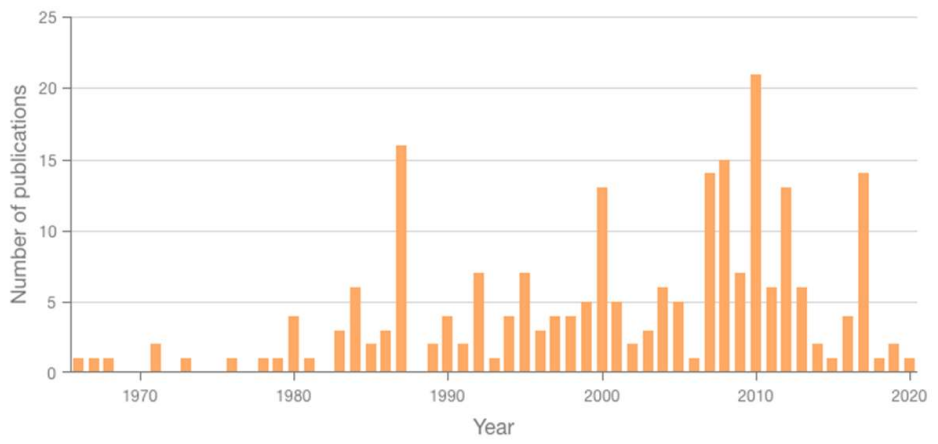

Kể từ năm 1947, 379 bài kỷ yếu hội thảo đã được phát hành. Trong đó, giai đoạn 1990-1999 và 20002009 lần lượt chiếm 34.6\% và $26.9 \%$ tổng số bài. Trong khi đó, giai đoạn $2010-2020$ chỉ chiếm 18.7\% tổng số bài (71 bài). Số lượng bài đăng kỷ yếu năm 2020 đạt mức thấp nhất kể từ năm 1990, có thể do tác động của đại dịch COVID-19 đến việc di chuyển quốc tế và tổ chức hội thảo.

Hình 7. Số lượng bài đăng kỷ yếu ngành toán từ 1947 đến 2020

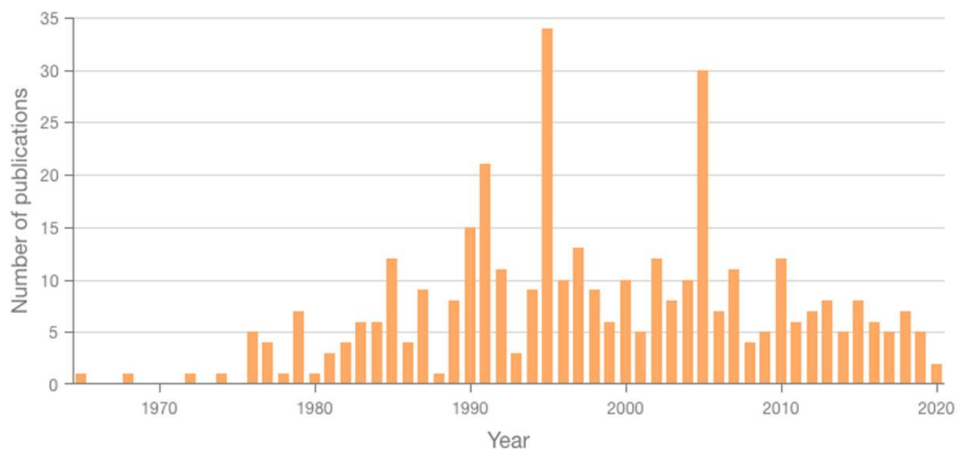

\subsection{Về tác giả}


Số lượng tác giả không thay đổi đáng kể từ năm 2010 đến 2016, thường biến động trong khoảng 300 đến 350 người/năm. Số lượng tác giả bắt đầu tăng mạnh từ năm 2017 (395 tác giả) và đạt đỉnh vào năm 2020 (609 tác giả).

Hình 8. Số lượng tác giả từ 2010 đến 2020

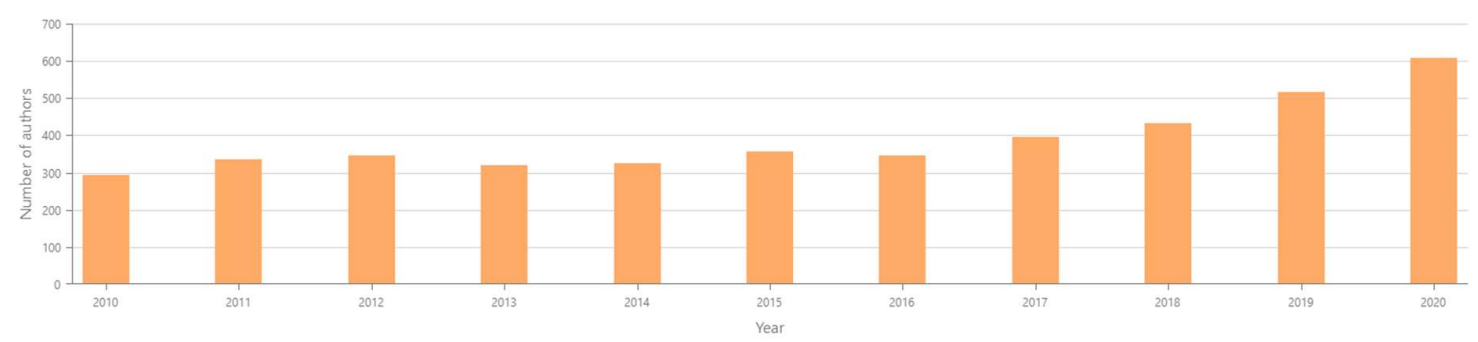

Độ trung bình của tác giả trong giai đoạn 2010-2020 là 40 tuổi (Hình 9). Lưu ý, con số này chỉ mang tính tham khảo vì nhân viên nhập liệu thường ước chừng năm sinh tác giả dựa trên thông tin CV (ví dụ, năm tốt nghiệp đại học), hoặc bỏ trống mục năm sinh tác giả nếu không có thông tin tham khảo.

Hình 9. Tuổi của tác giả trong giai đoạn 2010-2020

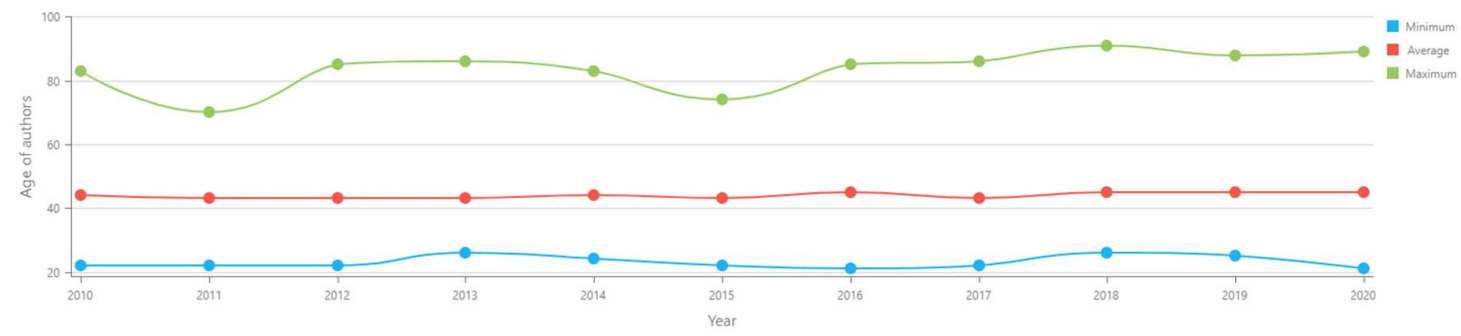

Mỗi năm, ngành toán đều có trên 60 tác giả có công bố quốc tế đầu tiên trong sự nghiệp (Hình 10). Số lượng tác giả mới biến động trong khoảng 57 đến 102 người trong giai đoạn 2010-2016. Từ năm 2016 trở đi, số lượng tác giả mới luôn tăng và đạt đỉnh vào năm 2020 (136 người).

Hình 10. Số lượng tác giả mới từ 2010 đến 2020

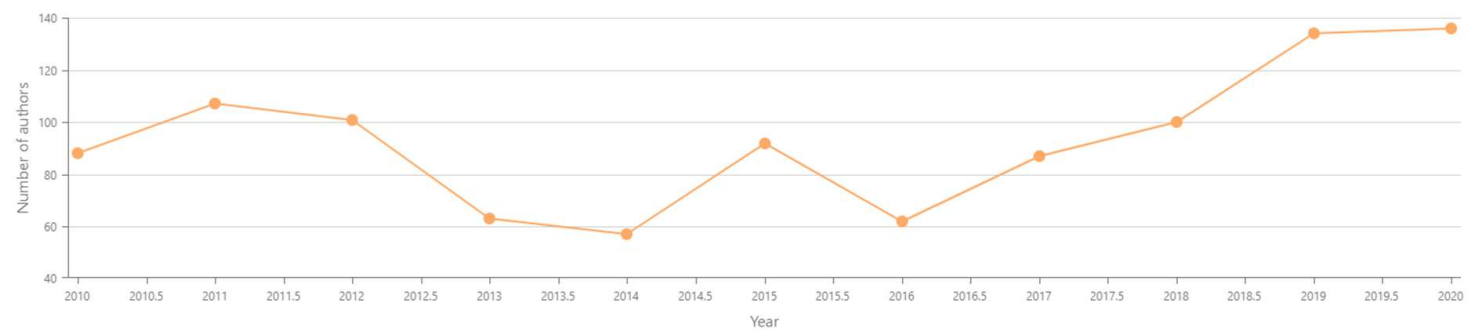

Theo Hình 11, một số tác giả có công bố lần đầu tiên khi đã vượt ngưỡng 50-60 tuổi. Một trong các nguyên nhân dẫn đến con số này có thể là do các công bố trước đó của các tác giả lớn tuổi chưa được cơ sở dữ liệu ghi nhận.

Hình 11. Tuổi trung bình, nhỏ nhất, lớn nhất của tác giả mới từ 2010 đến 2020 


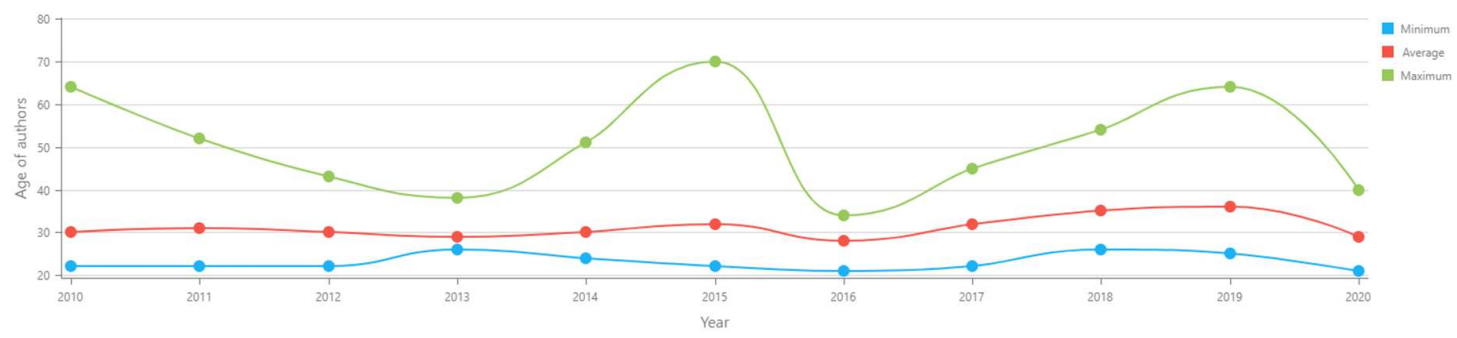

Nam giới chiếm tỷ lệ lớn trong ngành toán và sự chênh lệch về giới tính rất rõ ràng (Hình 12). Số lượng tác giả nữ có xu hướng tăng nhẹ từ năm 2010 (38 người) đến năm 2019 (82 người), và tăng đột biến vào năm 2020 (120 người). Do đó, tỷ lệ nữ tác giả đạt đỉnh là 19.7\% vào năm 2020, trong khi thường nằm trong khoảng $12 \%$ đến $15 \%$. Do sự chênh lệch giới tính, tác giả nữ xuất bản ít hơn đáng kể so với tác giả nam (Hình 13).

\section{Hình 12. Số lượng tác giả theo giới tính trong giai đoạn 2010-2020}

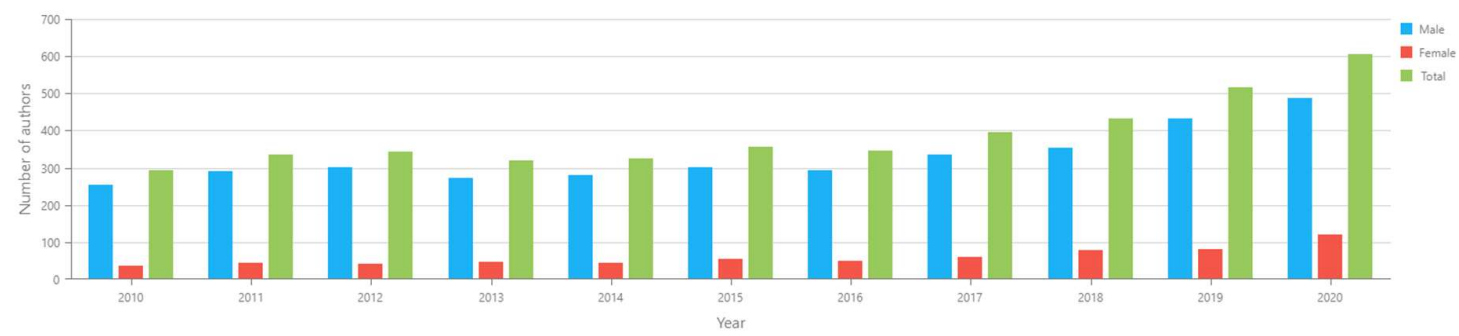

Hình 13. Số lượng nghiên cứu theo giới tính tác giả trong giai đoạn 2010-2020

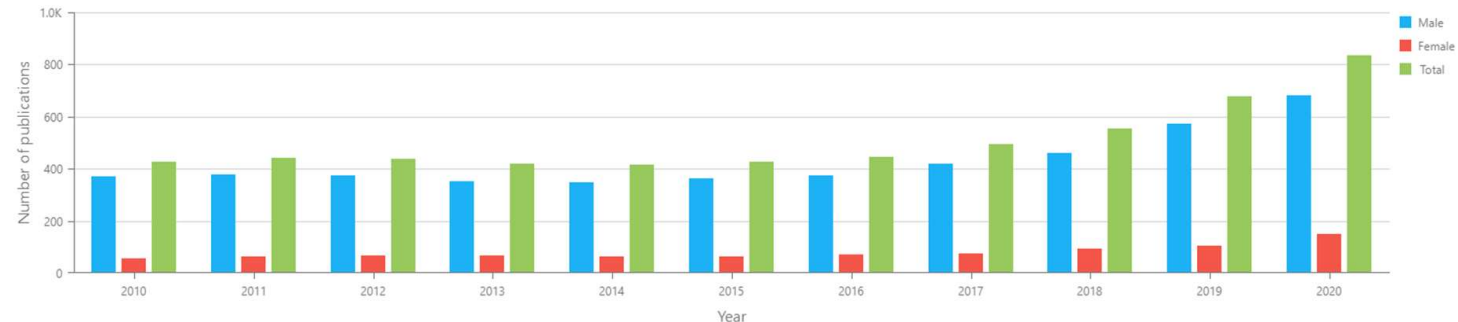

Bảng 1 là danh sách 12 tác giả có số lượng công bố cao nhất trong giai đoạn 2010-2020, trong đó có 3 tác giả ở các vị trí cuối cùng có số lượng bài bằng nhau. Trong đó 7 tác giả đã bắt đầu công bố quốc tế vào cuối thế kỷ 20 và vẫn bền bỉ nghiên cứu đến tận ngày nay.

Trong những người bắt đầu công bố từ những năm 2000, tác giả Nguyễn Hoài Minh đã công bố trên những tạp chí toán học hàng đầu như Annals of Mathematics, Duke Mathematical Journal và Inventiones Mathematicae, dù mới bắt đầu công bố vào năm 2005. Tác giả Đặng Văn Hiếu đã xuất bản 65 công bố quốc tế trong 7 năm.

Nguyễn Huy Tuấn, người công bố nhiều nhất trong 10 năm qua, có bài đầu tiên vào năm 2006. Anh cũng là tác giả có mạng lưới hợp tác nghiên cứu đồ sộ. Trong 15 năm, tác giả Nguyễn Huy Tuấn đã hợp tác với 56 người Việt và 19 người nước ngoài.

Bảng 1. Top 12 tác giả có số lượng công bố cao nhất giai đoạn 2010-2020

\begin{tabular}{|l|l|r|r|}
\hline STT & Tên tác giả & Số công bố & Năm xuất bản công bố đầu tiên \\
\hline 1 & Nguyễn Huy Tuấn & 154 & 2006 \\
\hline
\end{tabular}




\begin{tabular}{|l|l|r|r|}
\hline 2 & Phạm Hữu Tiệp & 94 & 1986 \\
\hline 3 & Cung Thế Anh & 85 & 2004 \\
\hline 4 & Lê Thị Hoài An & 67 & 1996 \\
\hline 5 & Phan Quốc Khánh & 67 & 1979 \\
\hline 6 & Vũ Ngọc Phát & 66 & 1980 \\
\hline 7 & Đặng Văn Hiếu & 65 & 2014 \\
\hline 8 & Vũ Hà Văn & 58 & 1996 \\
\hline 9 & Đặng Đức Trọng & 56 & 1994 \\
\hline 10 & Nguyễn Đông Yên & 51 & 2005 \\
\hline 11 & Nguyễn Hoài Minh & 51 & 2004 \\
\hline 12 & Sĩ Đức Quang & 51 & 1985 \\
\hline
\end{tabular}

Nhiều tác giả mới có công bố đầu tiên trong 10 năm gần đây nhưng có năng suất nghiên cứu tương đối cao, nổi bật là Đặng Văn Hiếu và Nguyễn Hữu Cần (Bảng 2). Trong 3 năm, tác giả Nguyễn Hữu Cần xuất bản 32 công bố quốc tế. Hiện nay, tác giả Nguyễn Hữu Cẩn đang công tác tại Khoa Toán-Thống Kê, Đại học Tôn Đức Thắng.

Bảng 2. Các tác giả trẻ có năng suất cao

\begin{tabular}{|l|r|r|}
\hline \multicolumn{1}{|c|}{ Tên tác giả } & Số công bố & Năm xuất bản công bố đầu tiên \\
\hline Đặng Văn Hiếu & 65 & 2014 \\
\hline Dương Việt Thông & 49 & 2011 \\
\hline Nguyễn Văn Hoàng & 39 & 2011 \\
\hline Ngô Văn Hoà & 38 & 2011 \\
\hline Lương Đăng Kỷ & 37 & 2011 \\
\hline Tăng Quốc Bảo & 34 & 2010 \\
\hline Nguyễn Hữu Cần & 32 & 2018 \\
\hline Phạm Văn Thắng & 28 & 2012 \\
\hline Phạm Hùng Quý & 27 & 2010 \\
\hline
\end{tabular}

\subsection{Về tạp chí quốc tế, sách và kỷ yếu:}

Từ năm 2010 đến 2020, các nhà toán học Việt đã công bố trên 691 tạp chí, 38 cuốn sách và 65 kỷ yếu hội thảo quốc tế (Bảng 3). Trong đó, hai tạp chí quốc tế được đăng nhiều nhất, Acta Mathematica Vietnamica và Vietnam Journal of Mathematics, đều do cơ quan Việt Nam xuất bản.

\section{Bảng 3.10 tạp chí có nhiều công bố nhất}




\begin{tabular}{|l|l|}
\hline \multicolumn{1}{|c|}{ Tên tạp chí } & \multicolumn{1}{|c|}{$\begin{array}{c}\text { Số lượng } \\
\text { công bố }\end{array}$} \\
\hline Acta Mathematica Vietnamica & 231 \\
\hline Vietnam Journal of Mathematics & 179 \\
\hline Journal of Mathematical Analysis and Applications & 130 \\
\hline Journal of Optimization Theory and Applications & 103 \\
\hline Journal of Algebra & 99 \\
\hline $\begin{array}{l}\text { Optimization A Journal of Mathematical Programming and } \\
\text { Operations Research }\end{array}$ & 90 \\
\hline Nonlinear Analysis & 87 \\
\hline Journal of Global Optimization & 66 \\
\hline Proceedings of the American Mathematical Society & 51 \\
\hline Mathematical Methods in the Applied Sciences & 50 \\
\hline
\end{tabular}

Bảng 4 liệt kê số lượng nghiên cứu trên 10 tạp chí toán học uy tín nhất thế giới trong giai đoạn 20102020 (danh sách xem tại: http://sym.math.ku.dk/about/internal/10-most-prestigious-new.pdf). Dữ liệu cho thấy hằng năm người Việt đều có nghiên cứu được đăng trên 10 tạp chí hàng đầu (Hình 14). Điều này có thể phản ánh một phần chất lượng nghiên cứu của người Việt.

Bảng 4. Số lượng nghiên cứu trên các tạp chí toán học uy tín nhất theo năm.

\begin{tabular}{|c|c|c|c|}
\hline Tên tạp chí & Năm & $\begin{array}{l}\text { Số } \\
\text { công } \\
\text { bố }\end{array}$ & Tác giả \\
\hline Advances in Mathematics & 2010 & 4 & $\begin{array}{c}\text { Đào Hải Long (Hoa Kỳ), Nguyễn Đặng Hồ Hải (Việt } \\
\text { Nam, Pháp), Nguyễn Sum (Việt Nam), Phạm Hữu } \\
\text { Tiệp (Hoa Kỳ), Trần Ngọc Nam (Việt Nam) }\end{array}$ \\
\hline Advances in Mathematics & 2011 & 5 & $\begin{array}{l}\text { Ngô Việt Trung (Việt Nam), Nguyễn Công Minh } \\
\text { (Việt Nam), Nguyễn Hữu Hội (Hoa Kỳ), Trần Vũ } \\
\text { Khanh (Việt Nam), Vũ Hà Văn (Hoa Kỳ) }\end{array}$ \\
\hline Annals of Mathematics & 2011 & 3 & $\begin{array}{l}\text { Nguyễn Hoài Minh (Hoa Kỳ), Phạm Hữu Tiệp (Hoa } \\
\text { Kỳ) }\end{array}$ \\
\hline Duke Mathematical Journal & 2011 & 1 & Nguyễn Hoài Minh (Hoa Kỳ) \\
\hline Inventiones mathematicae & 2011 & 2 & $\begin{array}{c}\text { Nguyễn Hoài Minh (Hoa Kỳ), Phạm Hữu Tiệp (Hoa } \\
\text { Kỳ) }\end{array}$ \\
\hline Acta Mathematica & 2011 & 1 & Vũ Hà Văn (Hoa Kỳ) \\
\hline Advances in Mathematics & 2012 & 4 & $\begin{array}{l}\text { Đinh Tiến Cường (Pháp), Ngô Việt Trung (Việt } \\
\text { Nam), Nguyễn Tiến Dũng (Pháp), Vũ Hà Văn (Hoa } \\
\text { Kỳ) }\end{array}$ \\
\hline $\begin{array}{l}\text { Journal für die reine und } \\
\text { angewandte Mathematik }\end{array}$ & 2012 & 1 & Phạm Hữu Tiệp (Hoa Kỳ) \\
\hline Duke Mathematical Journal & 2012 & 2 & Nguyễn Hữu Hội (Hoa Kỳ), Phạm Hữu Tiệp (Hoa Kỳ) \\
\hline Annals of Mathematics & 2013 & 2 & Ngô Bảo Châu (Hoa Kỳ), Phạm Hữu Tiệp (Hoa Kỳ) \\
\hline Advances in Mathematics & 2014 & 1 & Phạm Hữu Tiệp (Hoa Kỳ) \\
\hline Acta Mathematica & 2014 & 1 & Phạm Hoàng Hiệp (Việt Nam) \\
\hline Advances in Mathematics & 2015 & 4 & $\begin{array}{c}\text { Đinh Tiến Cường (Singapore), Nguyễn Duy Tân } \\
\text { (Việt Nam, Canada), Nguyễn Sum (Việt Nam), } \\
\text { Phạm Hữu Tiệp (Hoa Kỳ) }\end{array}$ \\
\hline
\end{tabular}




\begin{tabular}{|c|c|c|c|}
\hline $\begin{array}{l}\text { Journal für die reine und } \\
\text { angewandte Mathematik }\end{array}$ & 2015 & 1 & Phạm Hữu Tiệp (Hoa Kỳ) \\
\hline Advances in Mathematics & 2016 & 4 & $\begin{array}{l}\text { Nguyễn Trọng Toán (Hoa Kỳ), Nguyễn Văn Hoàng } \\
\text { (Israel), Phạm Hữu Tiệp (Hoa Kỳ), Vũ Hà Văn (Hoa } \\
\text { Kỳ) }\end{array}$ \\
\hline $\begin{array}{l}\text { Journal für die reine und } \\
\text { angewandte Mathematik }\end{array}$ & 2016 & 1 & Nguyễn Hồng Đức (Việt Nam, Đức) \\
\hline Duke Mathematical Journal & 2016 & 1 & Nguyễn Trọng Toán (Hoa Kỳ) \\
\hline Advances in Mathematics & 2017 & 3 & $\begin{array}{c}\text { Lữ Hoàng Chinh (Thuỵ Điển), Nguyễn Duy Tân (Việt } \\
\text { Nam, Canada), Phạm Hùng Quý (Việt Nam) }\end{array}$ \\
\hline $\begin{array}{l}\text { Journal für die reine und } \\
\text { angewandte Mathematik }\end{array}$ & 2017 & 1 & Lữ Hoàng Chinh (Thuy. Điển) \\
\hline Inventiones mathematicae & 2017 & 1 & Dương Hồng Phong (Hoa Kỳ) \\
\hline Geometry and Topology & 2017 & 1 & Lữ Hoàng Chinh (Thuỵ Điển, Pháp) \\
\hline $\begin{array}{l}\text { Journal für die reine und } \\
\text { angewandte Mathematik }\end{array}$ & 2018 & 1 & Lê Quý Thường (Việt Nam) \\
\hline Inventiones mathematicae & 2018 & 2 & $\begin{array}{l}\text { Đinh Tiến Cường (Singapore), Phạm Hữu Tiệp (Hoa } \\
\text { Kỳ) }\end{array}$ \\
\hline Acta Mathematica & 2018 & 1 & Phạm Hữu Tiệp (Hoa Kỳ) \\
\hline Advances in Mathematics & 2019 & 5 & $\begin{array}{c}\text { Nguyễn Đăng Hồ Hải (Việt Nam), Phạm Hùng Quý } \\
\text { (Việt Nam), Phạm Hữu Tiệp (Hoa Kỳ), Vũ Hà Văn } \\
\text { (Hoa Kỳ) }\end{array}$ \\
\hline $\begin{array}{l}\text { Journal für die reine und } \\
\text { angewandte Mathematik }\end{array}$ & 2019 & 1 & Dương Hồng Phong (Hoa Kỳ) \\
\hline Annals of Mathematics & 2019 & 1 & Phạm Hữu Tiệp (Hoa Kỳ) \\
\hline Duke Mathematical Journal & 2019 & 1 & Đinh Tiến Cường (Singapore) \\
\hline Inventiones mathematicae & 2019 & 2 & $\begin{array}{l}\text { Ngô Việt Trung (Việt Nam), Nguyễn Đăng Hợp (Việt } \\
\text { Nam) }\end{array}$ \\
\hline $\begin{array}{l}\text { Annales scientifiques de } \\
\text { I'École Normale Supérieure }\end{array}$ & 2020 & 1 & Lữ Hoàng Chinh (Pháp) \\
\hline Advances in Mathematics & 2020 & 4 & $\begin{array}{l}\text { Nguyễn Hoài Minh (Thuy. Sĩ), Phạm Hùng Quý (Việt } \\
\text { Nam), Phạm Hữu Tiệp (Hoa Kỳ) }\end{array}$ \\
\hline $\begin{array}{l}\text { Journal für die reine und } \\
\text { angewandte Mathematik }\end{array}$ & 2020 & 1 & Lữ Hoàng Chinh (Pháp) \\
\hline
\end{tabular}

Dưới đây là một số đặc điểm về các tác giả người Việt có công bố trên các tạp chí hàng đầu. Thứ nhất, nhiều tác giả đã sinh sống và làm việc lâu năm ở nước ngoài. Trong đó là những người có tên tuổi trong cộng đồng toán học quốc tế và vinh dự được mời đọc báo cáo tại Đại hội Toán học Thế giới (International Congresses of Mathematicians): Phạm Hữu Tiệp, Dương Hồng Phong, Ngô Bảo Châu, Vũ Hà Văn. Theo dữ liệu bảng 4 , phần lớn các công trình trên các tạp chí hàng đầu được xuất bản khi tác giả đang ở nước ngoài.

Thứ hai, trong số các tác giả đang làm việc tại Việt Nam và có công bố trên tạp chí top 10, đa số đang khoảng 40 tuổi. Đó là Nguyễn Hồng Đức (sinh năm 1979), Nguyễn Công Minh (1980), Nguyễn Đặng Hồ Hải (sinh năm 1981), Nguyễn Duy Tân (sinh năm 1981), Lê Quý Thường (sinh năm 1982), Phạm Hoàng Hiệp (sinh năm 1982), Nguyễn Đăng Hợp (sinh năm 1982) Phạm Hùng Quý (sinh năm 1983) và Trần Vũ Khanh (sinh năm 1983).

Thứ ba, phần lớn các nhà toán học trên được đào tạo bậc đại học và cao học ở nước ngoài, đặc biệt là bậc tiến sĩ. Hai trường hợp bảo vệ đề tài tiến sĩ tại Việt Nam là Trần Ngọc Nam và Nguyễn Sum. Cả 
hai đều được hướng dẫn bởi GS. TSKH. Nguyễn Hữu Việt Hưng và bảo vệ tại trường Đại học Khoa học Tự nhiên, Đại học Quốc gia Hà Nội. Tác giả Trần Ngọc Nam còn được hướng dẫn bởi GS. TSKH. Lionel Schwartz, và Nguyễn Sum còn được hướng dẫn bởi GS. TS. Huỳnh Mùi.

Thứ tư, so sánh Bảng 4 và Bảng 1 (các tác giả có nhiều công bố nhất), chỉ có ba tác giả vừa có số lượng công bố cao và vừa có nghiên cứu trên tạp chí uy tín nhất. Đó là Phạm Hữu Tiệp, Vũ Hà Văn và Nguyễn Hoài Minh. Cả ba đều công tác tại nước ngoài.

Cuối cùng, tất cả các tác giả trong Bảng 4 là nam giới. Có thể thấy, nữ giới không chỉ chiếm tỷ lệ nhỏ trong cộng đồng toán học Việt (Hình 12 và 13), mà còn vắng mặt trên các tạp chí hạng cao.

Hình 14 tổng kết lại tình hình công bố trên tạp chí toán học uy tín nhất. Hiện nay, Advances in Mathematics là tạp chí hàng đầu mà người Việt xuất hiện nhiều nhất. Hai tạp chí top 10 không có bài đăng nào trong 10 năm qua là Journal of the American Mathematical Society và Publications Mathématiques de I'IHÉS.

\section{Hình 14. Số nghiên cứu đăng trên các tạp chí uy tín theo năm}

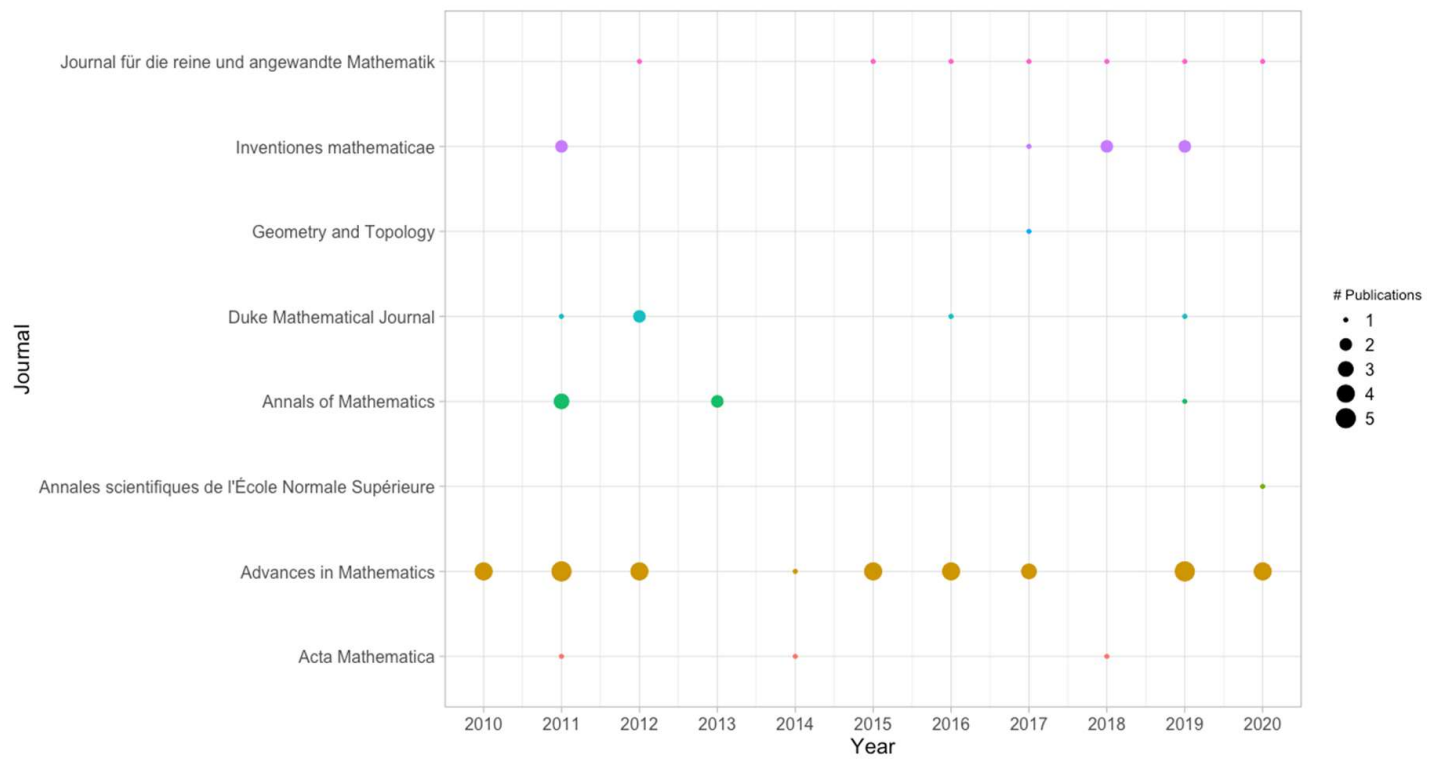

\subsection{Về cơ sở nghiên cứu}

Dữ liệu SciMath cho thấy sự chênh lệch năng suất lớn giữa các cơ sở nghiên cứu. Trong hơn 300 cơ quan tại Việt Nam, chỉ 13 cơ sở nghiên cứu có trên 100 công bố, và hơn $50 \%$ tổng số các cơ sở nghiên cứu có dưới 10 công bố.

Tình trạng chênh lệch năng suất cũng xảy ra giữa 10 cơ sở có nhiều công bố nhất (Bảng 5). Theo cách phân cấp cơ sở nghiên cứu của SciMath (xem mục 2.2 phần Cơ sở dữ liệu SciMath), Viện Toán Học là đơn vị dẫn đầu về số lượng công bố (791 nghiên cứu). Khoa Toán Thống Kê (Trường Đại học Tôn Đức Thắng) ${ }^{1}$ và Khoa Toán-Tin (Trường Đại học Sư Phạm Hà Nội) lần lượt đứng thứ 2 và thứ 3 . Các cơ sở nghiên cứu có số lượng công bố lớn tập trung nhiều tác giả. Ngoài ra, ngoại trừ Khoa Toán (Đại học Vinh), các cơ quan nghiên cứu trong Bảng 5 đều có trụ sở ở Hà Nội và TP. Hồ Chí Minh.

\footnotetext{
${ }^{1}$ Tính tổng số lượng công bố của tất cả các khoa, viện nghiên cứu trực thuộc, Trường Đại học Tôn Đức Thắng có khoảng 600 nghiên cứu (một số nghiên cứu có thể bị tính nhiều lần do sự hợp tác giữa các khoa hoặc một nghiên cứu viên trực thuộc tại nhiều khoa).
} 
Bảng 5.10 cơ sở nghiên cứu có số lượng công bố quốc tế cao nhất

\begin{tabular}{|l|l|l|}
\hline \multicolumn{1}{|c|}{ Cơ sở nghiên cứu } & \multicolumn{1}{|c|}{$\begin{array}{c}\text { Số lượng } \\
\text { công bố }\end{array}$} & Số tác giả \\
\hline $\begin{array}{l}\text { Viện Toán học (Viện Hàn lâm Khoa học Công nghệ Việt } \\
\text { Nam) }\end{array}$ & 791 & 485 \\
\hline Khoa Toán Thống Kê (Trường Đại học Tôn Đức Thắng) & 443 & 330 \\
\hline Khoa Toán-Tin (Trường Đại học Sư Phạm Hà Nội) & 415 & 224 \\
\hline $\begin{array}{l}\text { Trường Đại học Khoa học Tự nhiên (Đại học Quốc gia TP. } \\
\text { Hồ Chí Minh) }\end{array}$ & 390 & 276 \\
\hline $\begin{array}{l}\text { Trường Đại học Khoa học Tự nhiên (Đại học Quốc gia Hà } \\
\text { Nội) }\end{array}$ & 359 & 254 \\
\hline Trường Đại học Quốc tế (Đại học Quốc gia TP. Hồ Chí Minh) & 168 & 102 \\
\hline Viện Toán Ứng dụng và Tin học (Đại học Bách khoa Hà Nội) & 165 & 156 \\
\hline Khoa Toán (Đại học Vinh) & 137 & 112 \\
\hline Viện Khoa học Tính toán (Trường Đại học Tôn Đức Thắng) & 133 & 151 \\
\hline
\end{tabular}

Tương tự như cách tính tác giả mới, SciMath coi một cơ quan là cơ sở nghiên cứu mới dựa vào năm xuất bản nghiên cứu đầu tiên. 2010-2020 là dấu mốc quan trọng vì có nhiều cơ sở nghiên cứu mới. Trước năm 2009, hàng năm nước ta có thêm 10 cơ sở nghiên cứu mới. Trong khi đó, từ năm 2010 đến 2020, số cơ sở nghiên cứu mới hàng năm dao động từ 10 đến 30 đơn vị (Hình 15).

Hình 15. Số lượng cơ sở nghiên cứu mới theo năm

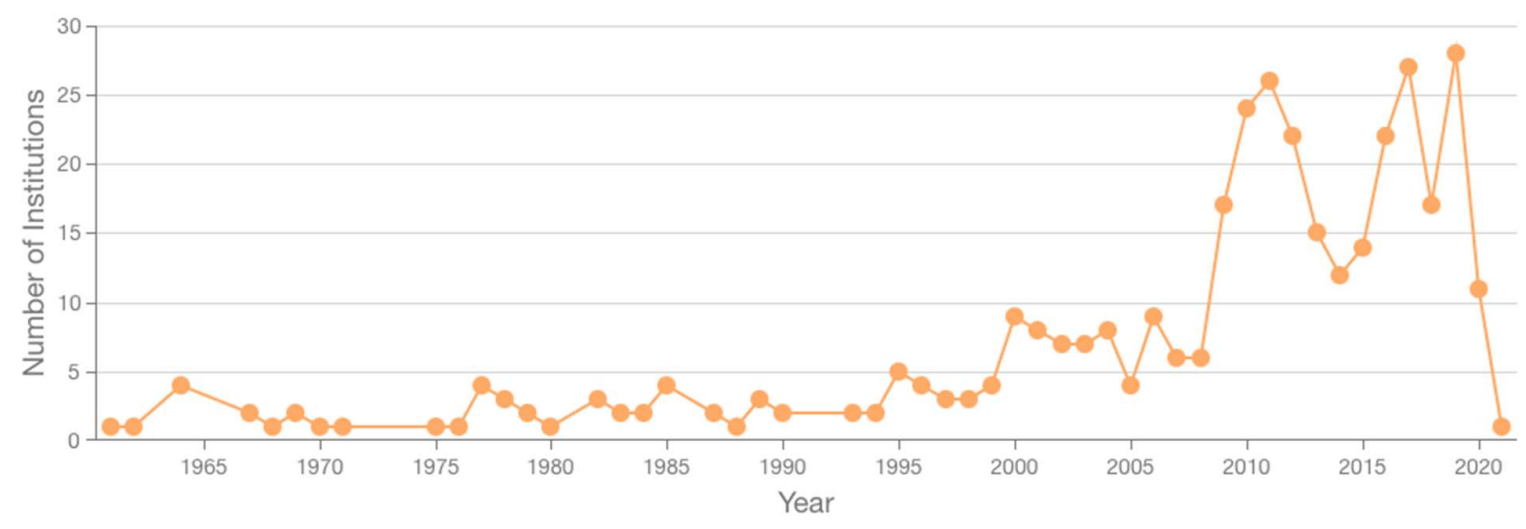

Sự tập trung của các cơ sở nghiên cứu có năng suất cao tại các thành phố lớn có thể thúc đẩy sự chênh lệch năng suất nghiên cứu khoa học giữa các tỉnh, thành phố. Tuy nhiên, mạng lưới nghiên cứu dày dặc giữa các thành phố lớn (Hà Nội, TP. Hồ Chí Minh) với các tỉnh/ thành phố khác giúp khai thác tiềm năng phát triển toán học trên toàn quốc (Hình 16).

Hình 16. Mạng lưới hợp tác nghiên cứu của Hà Nội với các tỉnh/ thành phố khác. 


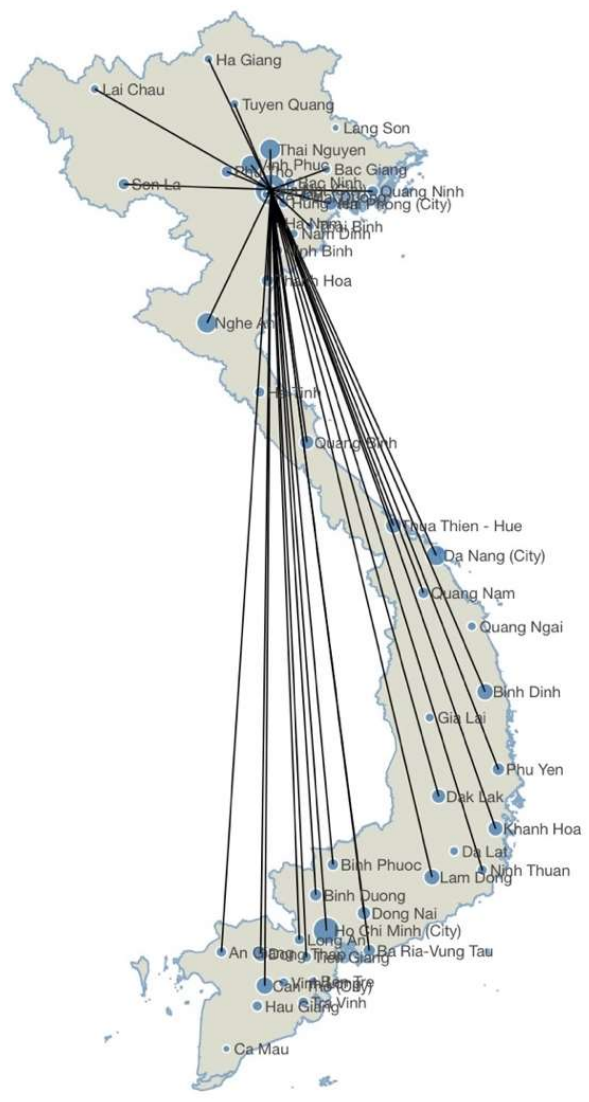

\subsection{Về hợp tác nghiên cứu}

Trong giai đoạn 2010-2020, mạng lưới hợp tác của các tác giả Việt Nam đã phát triển dày đặc. Trong hình 17, hạt màu xanh dương đại diện tác giả nam người Việt, màu xanh lá đại diện tác giả nữ người Việt và màu cam đại diện tác giả nước ngoài. Một số ví dụ về nhóm hợp tác nghiên cứu đông thành viên của Việt Nam là nhóm của tác giả Nguyễn Huy Tuấn (Hình 18) và Cung Thế Anh (Hình 19). Bên ngoài rìa hình cầu có các nhóm hợp tác nhỏ không có liên kết với bất cứ nhóm ngoài nào, thí dụ như nhóm của tác giả Phạm Hữu Tiệp (Hình 20) và Nguyễn Trọng Toán (Hình 21). Tuy nhiên, phần lớn các nhóm nghiên cứu đều hợp tác nghiên cứu với nhóm khác, được thể hiện bởi các các đường nối chằng chịt giữa các nhóm nghiên cứu.

Hình 17 thể hiện mạng lưới hợp tác nghiên cứu toán học của Việt Nam giai đoạn 2010-2020. Nhóm nghiên cứu của tác giả Nguyễn Huy Tuấn, Cung Thế Anh, Phạm Hữu Tiệp, Nguyễn Trọng Toán lần lượt được đánh dấu $1,2,3$ và 4 .

Hình 17. Mạng lưới hợp tác nghiên cứu toán học của Việt Nam giai đoạn 2010-2020 




Dưới đây là mạng lưới hợp tác của tác giả Nguyễn Huy Tuấn, Cung Thế Anh, Phạm Hữu Tiệp, Nguyễn Trọng Toán. Hạt đại diện các tác giả trên sẽ được khoanh đậm để phân biệt.

Hình 18. Mạng lưới hợp tác của tác giả Nguyễn Huy Tuấn (nhóm số 1 Hình 17) 


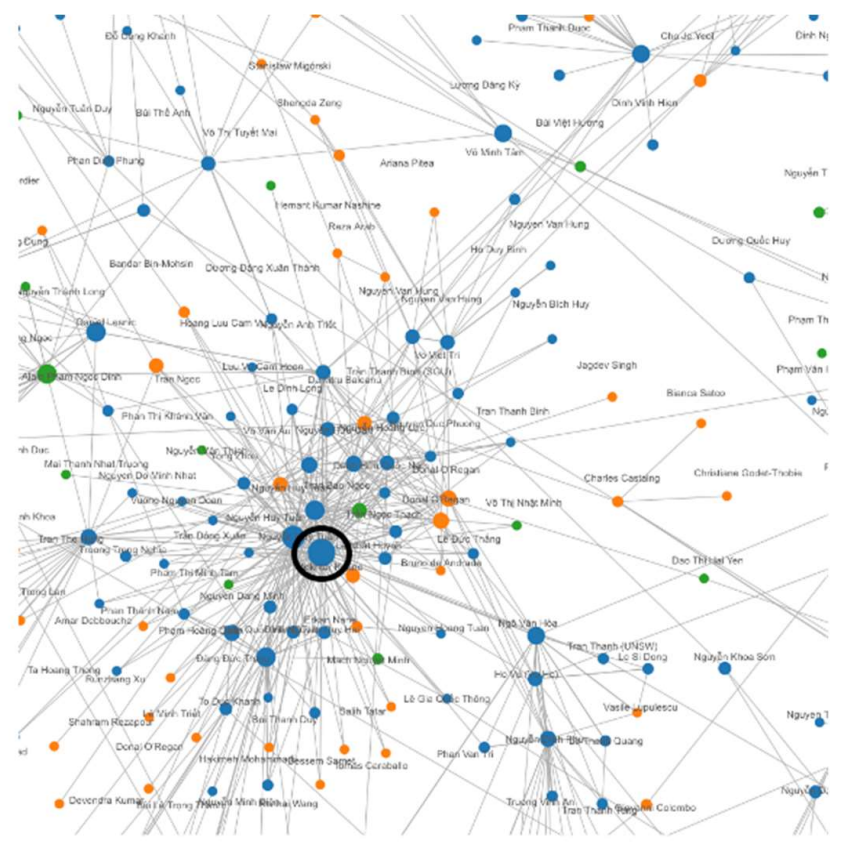

Hình 19. Mạng lưới hợp tác của tác giả Cung Thế Anh (nhóm số 2 Hình 17)

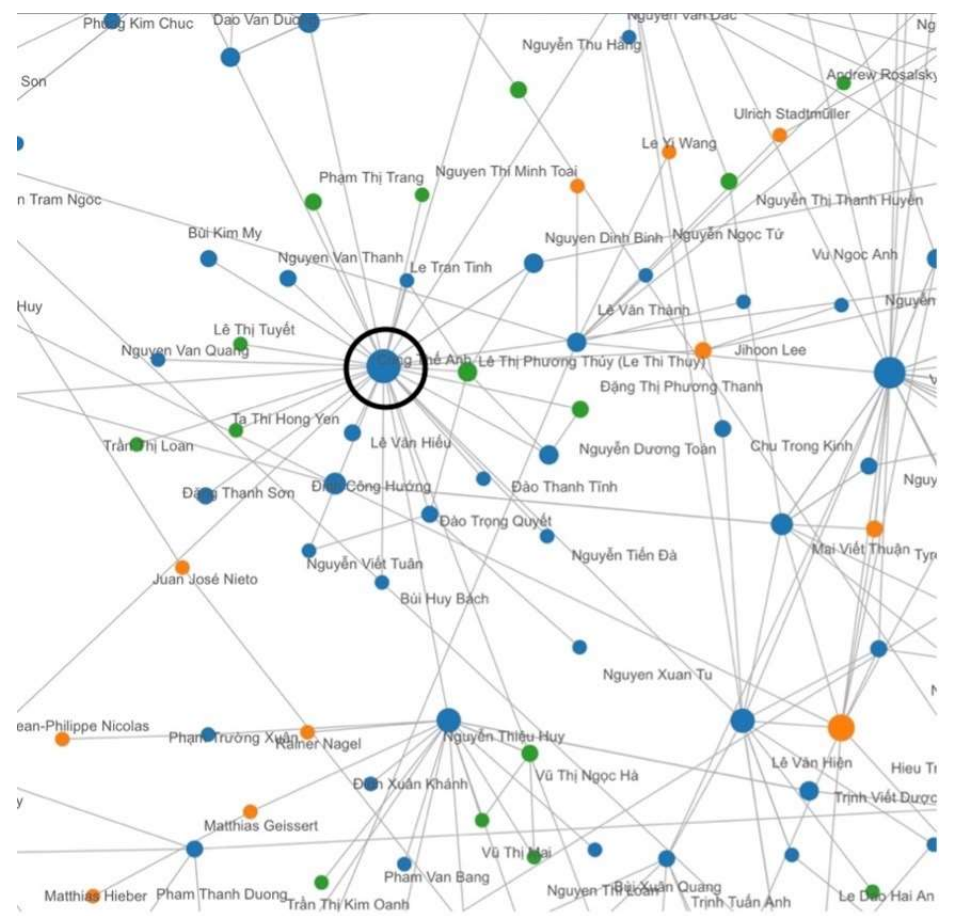

Hình 20. Mạng lưới hợp tác của tác giả Phạm Hữu Tiệp (nhóm số 3 Hình 17) 


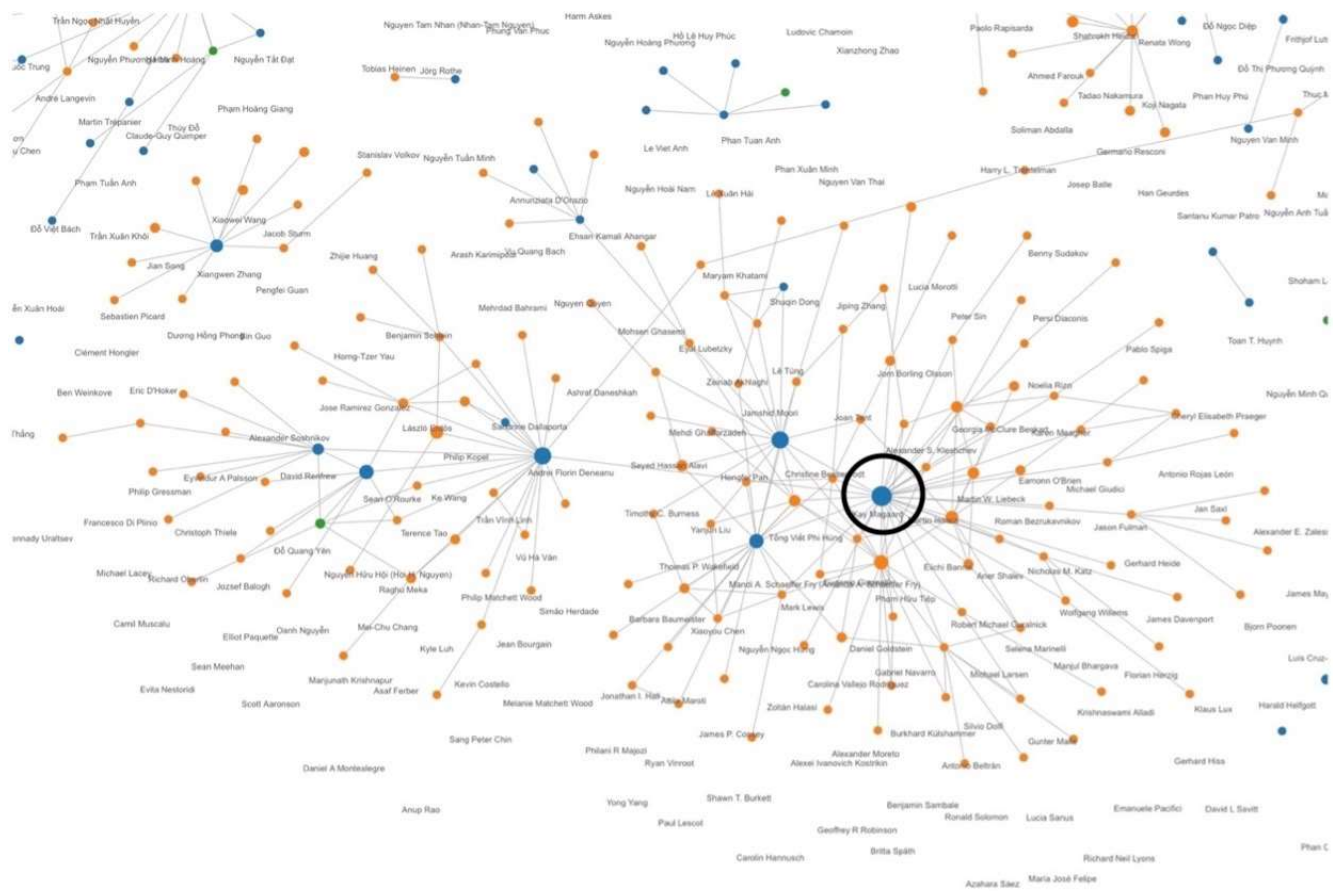

Hình 21. Mạng lưới hợp tác của tác giả Nguyễn Trọng Toán (nhóm số 4 Hình 17)

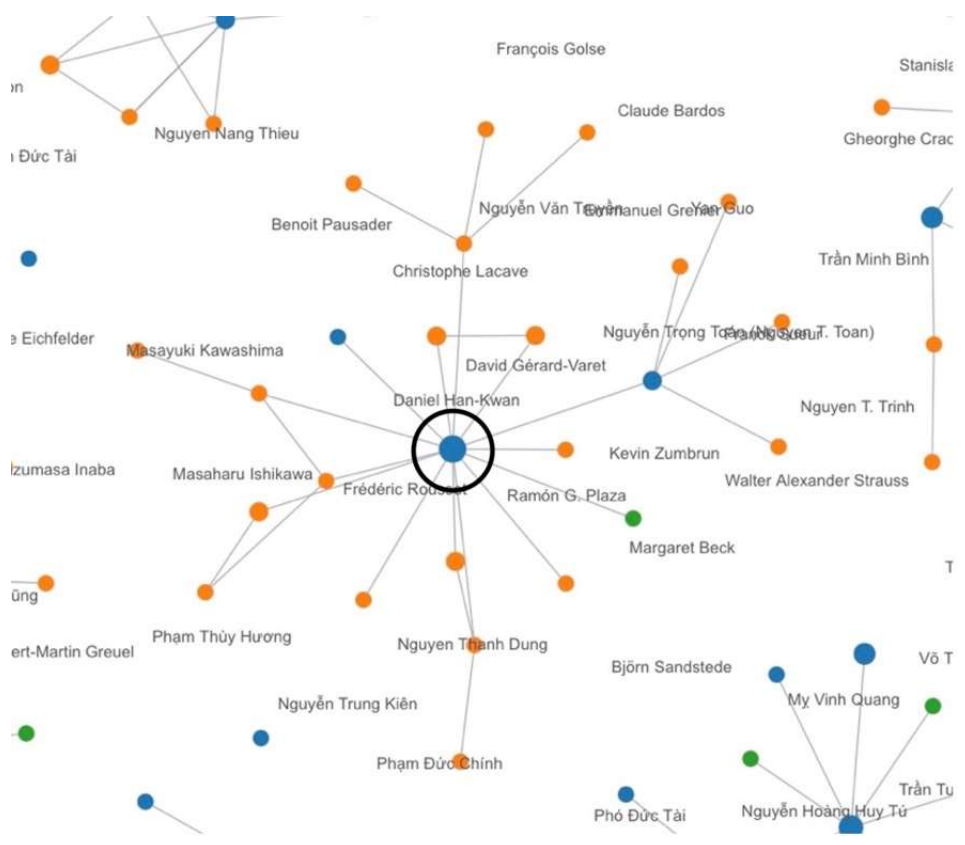

Dù hợp tác là xu hướng mới trong các năm gần đây, 1075 trong tổng số 4857 công bố thuộc giai đoạn 2010-2020 được viết bởi một tác giả duy nhất (Hình 22). Nhóm nhỏ từ 2 đến 3 người là loại hợp tác thường thấy nhất. Số lượng công bố của nhóm tác giả từ 5 đến 8 người chiếm tỷ trọng nhỏ.

Hình 22. Số công bố theo số lượng đồng tác giả trong giai đoạn 2010-2020 


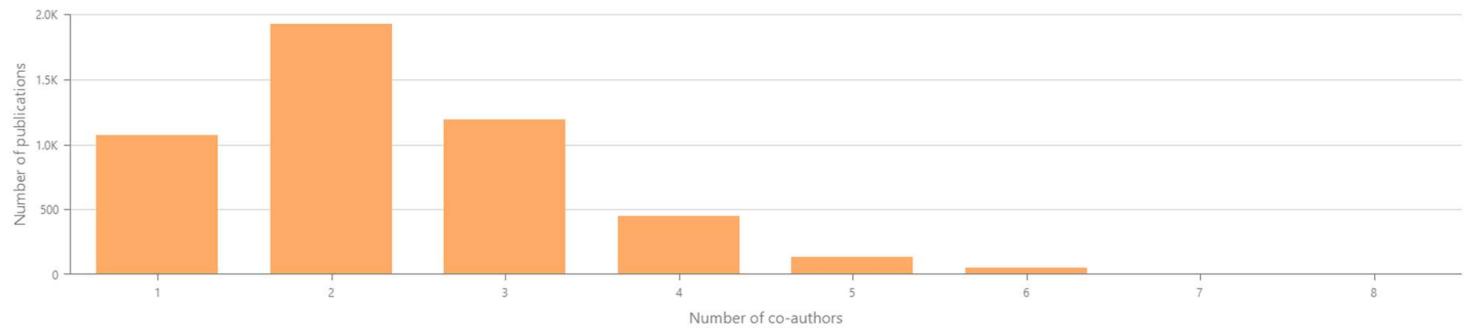

\subsection{Về phân ngành}

Trong giai đoạn 2010-2020, công bố toán học của người Việt trải rộng 63 phân ngành. Bảng 6 liệt kê 10 phân ngành được nghiên cứu có nhiều công bố nhất, cho thấy các phân ngành nổi bật nhất bao gồm: Partial differential equations, Operations research, mathematical programming, và Operator theory.. Lưu ý, một nghiên cứu có thể thuộc nhiều phân ngành khác nhau.

\section{Bảng 6. 10 ngành có nhiều công bố nhất}

\begin{tabular}{|l|l|}
\hline \multicolumn{1}{|c|}{ Ngành } & Số lượng công bố \\
\hline Partial differential equations & 967 \\
\hline Operations research, mathematical programming & 754 \\
\hline Operator theory & 695 \\
\hline Calculus of variations and optimal control; optimization & 623 \\
\hline Numerical analysis & 527 \\
\hline Ordinary differential equations & 407 \\
\hline Several complex variables and analytic spaces & 330 \\
\hline Probability theory and stochastic processes & 299 \\
\hline Commutative algebra & 274 \\
\hline Group theory and generalizations & 244 \\
\hline
\end{tabular}

Ngành Partial differential equations có số lượng công bố tăng đột biến từ năm 2015, và từ đó luôn là ngành có số lượng nghiên cứu cao nhất (Hình 23). Trước 2015, các ngành top 10 không có sự chênh lệch đáng kể về số lượng công bố. Một số ngành có xu hướng tăng nhẹ về số lượng công bố trong giai đoạn 2010-2020 là Operator theory, Operations research and mathematical programming, Numerical analysis, và Calculus of variations and optimal control; optimization.

Hình 23. Số lượng công bố của các ngành nổi bật theo năm 
Publications by top subjects $(2010-2020)$

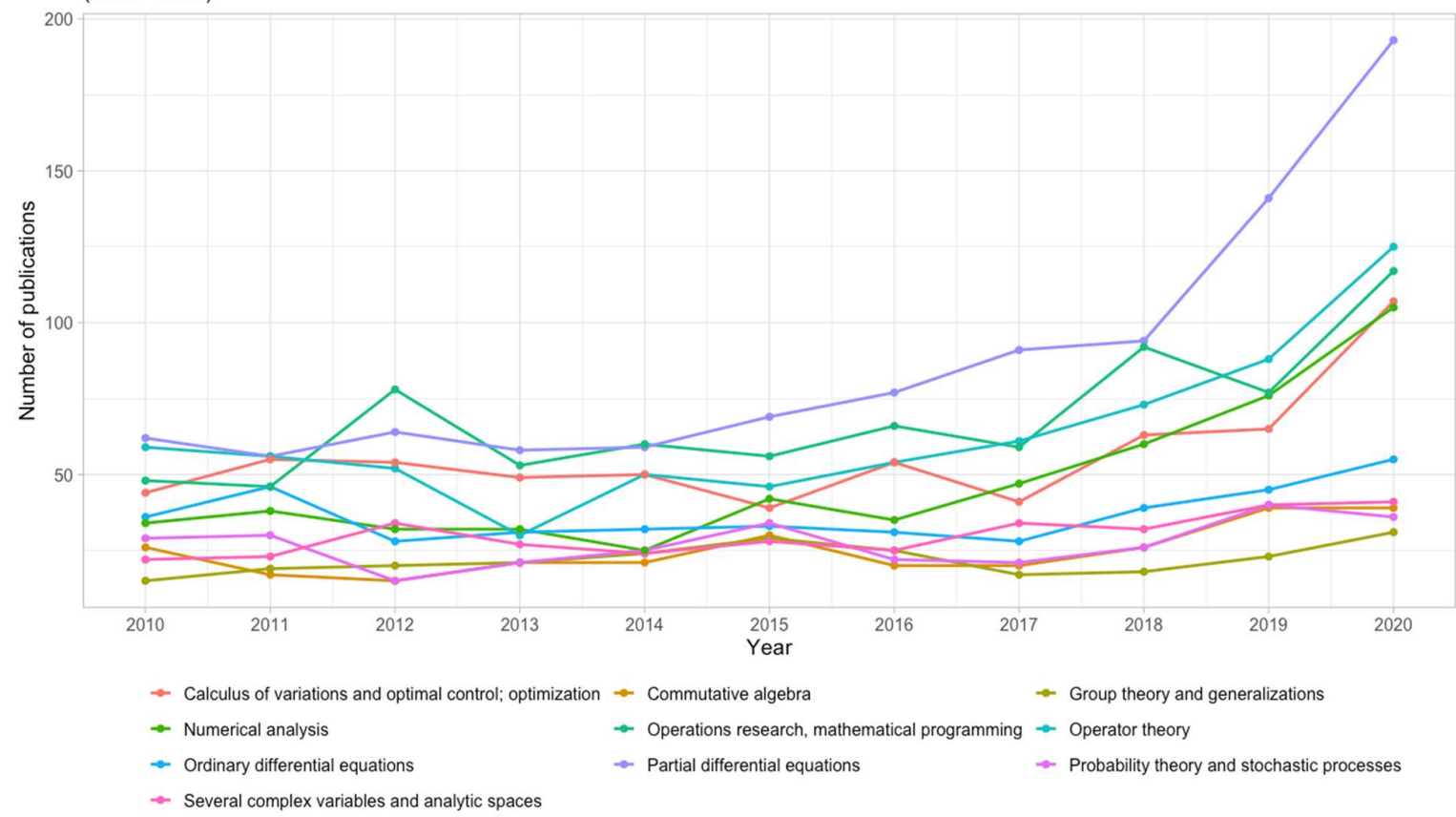

Tất cả 10 phân ngành trên đều thuộc nhóm 15 phân ngành có số lượng tác giả cao nhất. Bảng 7 liệt kê 10 ngành có số lượng tác giả cao nhất. Với số lượng công bố cao nhất, ngành Partial differential equations có nhiều tác giả nhất (613 người) do số lượng tăng nhanh từ 2015 (Hình 24). Số lượng tác giả ngành Operations research, mathematical programming ít hơn ngành Operator theory và Numerical analysis, nhưng số lượng công bố cao hơn.

Bảng 7. 10 ngành có số lượng tác giả cao nhất

\begin{tabular}{|l|l|l|}
\hline \multicolumn{1}{|c|}{ Ngành } & Số lượng công bố & Số lượng tác giả \\
\hline Partial differential equations & 967 & 613 \\
\hline Numerical analysis & 527 & 523 \\
\hline Operator theory & 695 & 487 \\
\hline Operations research, mathematical programming & 754 & 442 \\
\hline Calculus of variations and optimal control; optimization & 623 & 375 \\
\hline Ordinary differential equations & 407 & 334 \\
\hline Probability theory and stochastic processes & 299 & 246 \\
\hline Systems theory; control & 228 & 206 \\
\hline Real functions & 178 & 189 \\
\hline Several complex variables and analytic spaces & 330 & 187 \\
\hline
\end{tabular}

Hình 24. Số lượng tác giả theo ngành và năm trong giai đoạn 2010-2020 
Publications by top subjects $(2010$ - 2020)

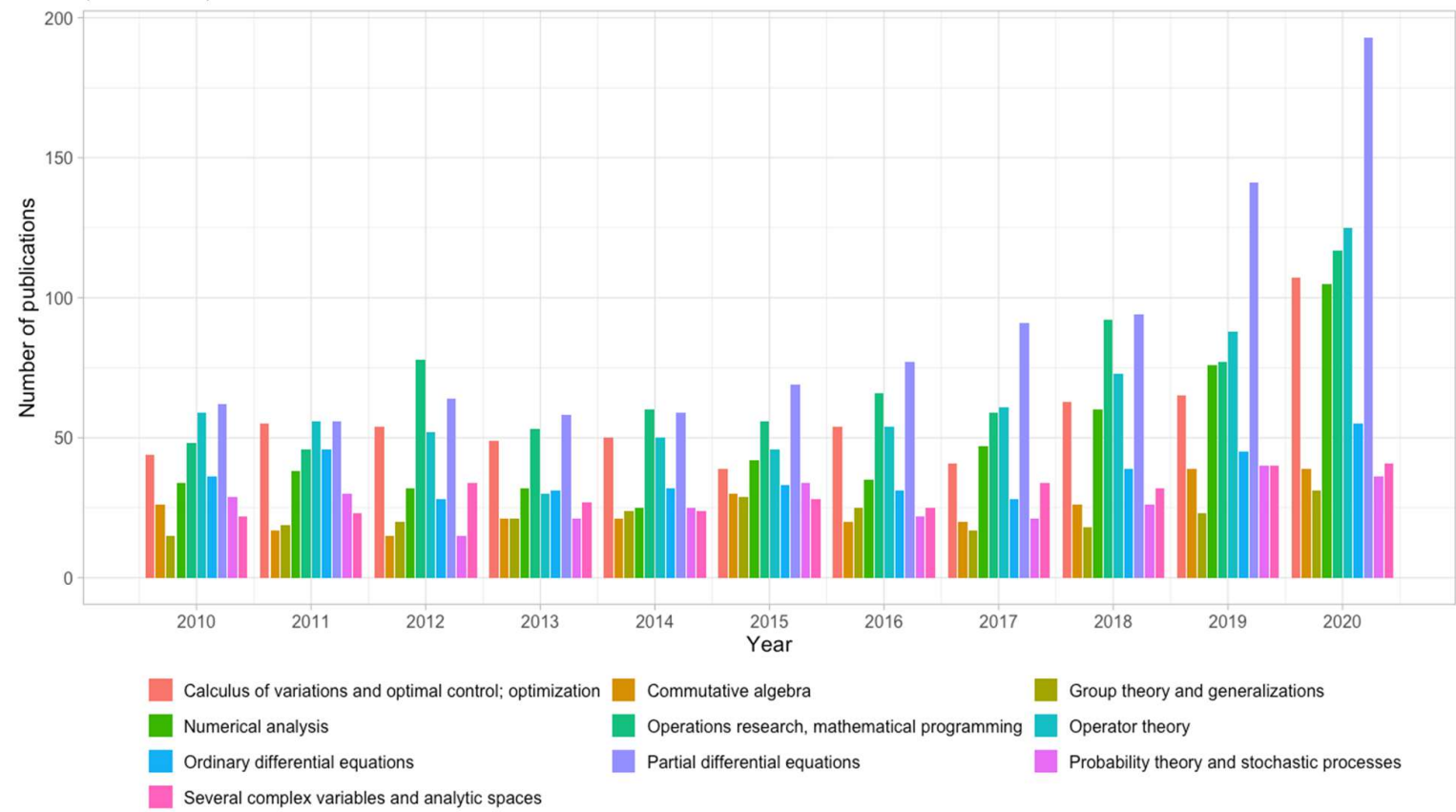

\section{Các biến động của một số phân ngành giai đoạn 2010-2020}

Phần 4 phân tích một số khía cạnh của các phân ngành lớn như số lượng công bố, cơ quan nghiên cứu và tác giả có năng suất nghiên cứu cao. Ngoài ra, mối quan hệ hợp tác giữa các tác giả trong ngành hoặc giữa người Việt và người nước ngoài sẽ được phân tích kỹ hơn.

\subsection{Ngành Partial differential equations}

Năng suất nghiên cứu ngành Partial differential equations mới bắt đầu phát triển vào cuối những năm 2000, và tăng mạnh sau năm 2010 (Hình 25). Theo CSDL SciMath, 61.28\% nghiên cứu ngành Partial differential equations được xuất bản sau 2010.

Hình 25. Năng suất nghiên cứu hằng năm ngành Partial differential equations

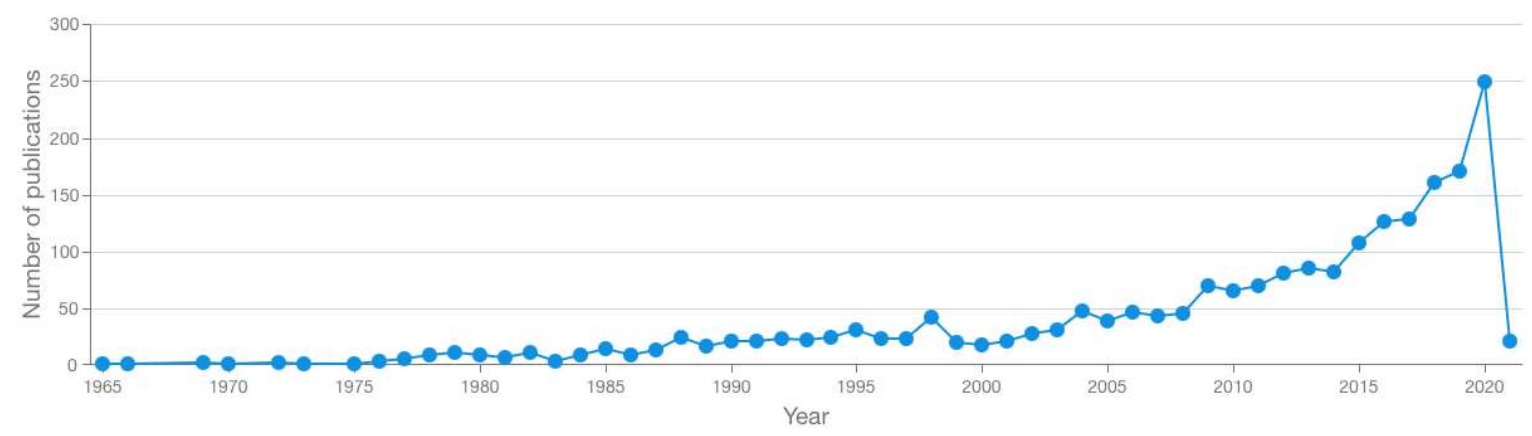

Hiện nay, ba cơ sở có nhiều công bố nhất ngành Partial differential equations là Đại học Khoa học Tự nhiên (Đại học Quốc gia TP. HCM), Khoa Toán-Thống kê của Trường Đại học Tôn Đức Thắng và Khoa Toán-Tin của Trường Đại học Sư phạm Hà Nội (Bảng 8). Ba cơ sở này chiếm khoảng $50 \%$ nghiên cứu ngành Partial differential equations. Ngoài ra, 8 trên 10 cơ quan nghiên cứu trong Bảng 8 được đặt tại Hà Nội và TP. Hồ Chí Minh. 
Ba cơ sở nghiên cứu trên là nơi làm việc của các tác giả năng suất nhất ngành (Bảng 9). Nguyễn Huy Tuấn, người có nhiều công bố nhất (137 bài), hiện công tác tại Khoa Toán-Thống kê của Trường Đại học Tôn Đức Thắng. Tác giả Cung Thế Anh ( 83 bài) và Tăng Quốc Bảo (33 bài) làm việc tại Khoa ToánTin của Trường Đại học Sư phạm Hà Nội. Đặng Đức Trọng (44 bài) và Nguyễn Thành Long (40 bài) công tác tại Trường Đại học Khoa học Tự nhiên (Đại học Quốc gia TP. HCM). Trong các tác giả được liệt kê có một số người khá trẻ, đó là Nguyễn Thành Chung (sinh năm 1982), Tăng Quốc Bảo (sinh năm 1988) và Nguyễn Trọng Toán (sinh năm 1980).

Bảng 8. Các cơ sở nghiên cứu năng suất nhất ngành Partial differential equations

\begin{tabular}{|l|r|}
\hline \multicolumn{1}{|c|}{ Cơ sở nghiên cứu } & Số công bố \\
\hline Trường Đại học Khoa học Tự nhiên (Đại học Quốc gia TP. Hồ Chí Minh) & 179 \\
\hline Khoa Toán Thống Kê (Trường Đại học Tôn Đức Thắng) & 173 \\
\hline Khoa Toán-Tin (Trường Đại học Sư Phạm Hà Nội) & 134 \\
\hline Viện Toán học (Viện Hàn lâm Khoa học Công nghệ Việt Nam) & 68 \\
\hline Viện Toán Ứng dụng và Tin học (Đại học Bách khoa Hà Nội) & 67 \\
\hline Viện Nghiên cứu và Phát triển Công nghệ cao (Đại học Duy Tân) & 64 \\
\hline Trường Đại học Khoa học Tự nhiên (Đại học Quốc gia Hà Nội) & 46 \\
\hline Khoa Toán-ứng Dụng (Đại học Sài Gòn) & 42 \\
\hline Khoa Khoa học Cơ bản (Trường Đại học Quảng Bình) & 40 \\
\hline Viện Khoa học Tính toán (Trường Đại học Tôn Đức Thắng) & 36 \\
\hline
\end{tabular}

Bảng 9. Các tác giả có nhiều công bố nhất ngành Partial differential equations

\begin{tabular}{|l|r|r|}
\hline \multicolumn{1}{|c|}{ Tên tác giả } & Số công bố & Năm xuất bản nghiên cứu đầu tiên \\
\hline Nguyễn Huy Tuấn & 137 & 2006 \\
\hline Cung Thế Anh & 83 & 2004 \\
\hline Nguyễn Thành Chung & 46 & 2009 \\
\hline Đặng Đức Trọng & 44 & 1994 \\
\hline Nguyễn Thành Long & 40 & 1986 \\
\hline Lê Thị Phương Ngọc & 39 & 1996 \\
\hline Tăng Quốc Bảo & 33 & 2010 \\
\hline Nguyễn Trọng Toán & 31 & 2003 \\
\hline
\end{tabular}

Hình 26 thể hiện mạng lưới hợp tác ngành Partial differential equations. Hai nhóm đông thành viên nhất là nhóm của tác giả Nguyễn Huy Tuấn và Cung Thế Anh, lần lượt được đánh dấu 1 và 2 trong Hình 26. Tuy có mối quan hệ hợp tác giữa các nhóm nghiên cứu, mối quan hệ này chưa sâu sắc, nên khoảng cách giữa các nhóm tương đối xa. Độ lớn của hình cầu cũng cho thấy số lượng tác giả lớn tham gia nghiên cứu mảng này.

Hình 26. Mạng lưới hợp tác ngành Partial differential equations 


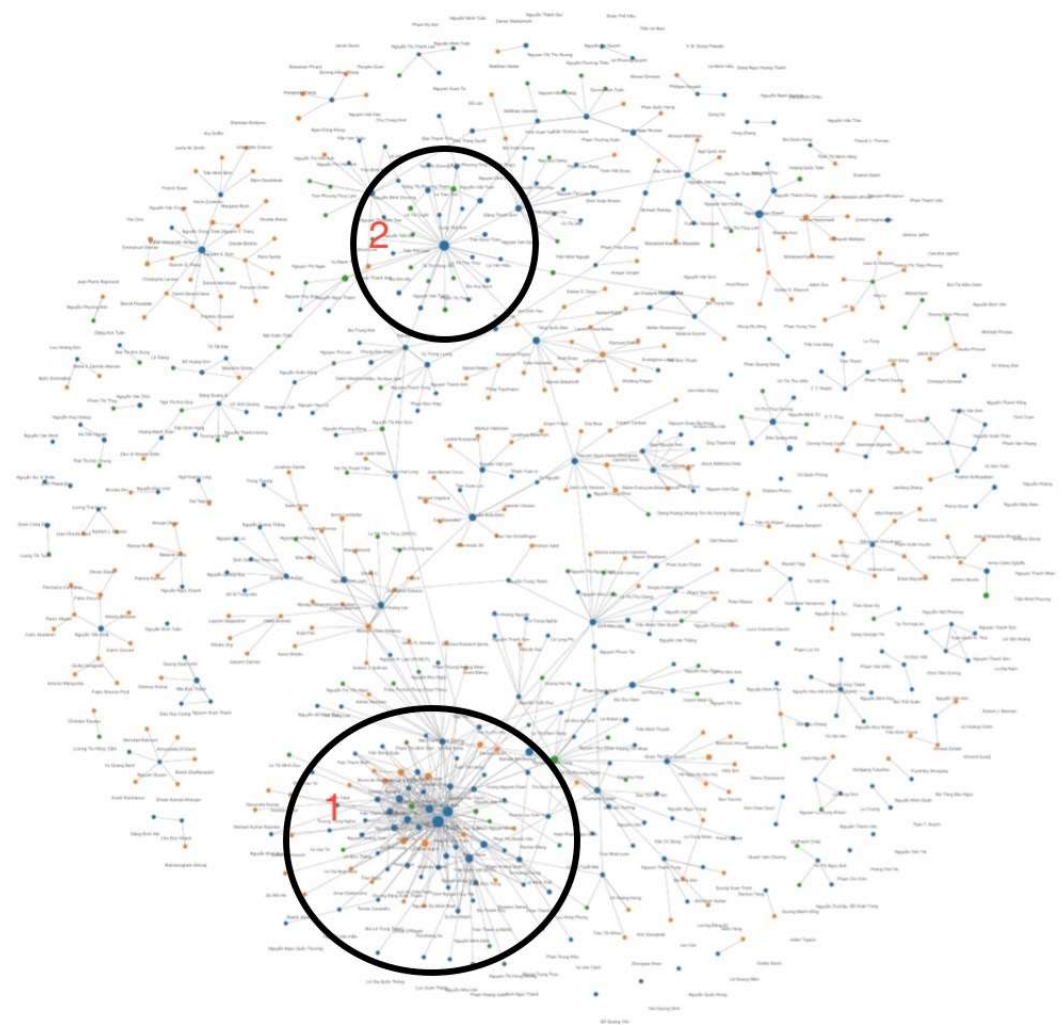

\subsection{Ngành Operations research, mathematical programming}

Tương tự ngành Partial differential equations, năng suất ngành Operations research, mathematical programming tăng nhanh sau năm 2010, dù xu hướng nghiên cứu được hình thành từ những năm 1990 (Hình 27). Trong 1384 nghiên cứu kể từ năm 1963 đến 2020, 754 bài (tương đương 54.48\%) được xuất bản trong giai đoạn 2010-2020.

Hình 27. Năng suất nghiên cứu hằng năm ngành Operations research, mathematical programming

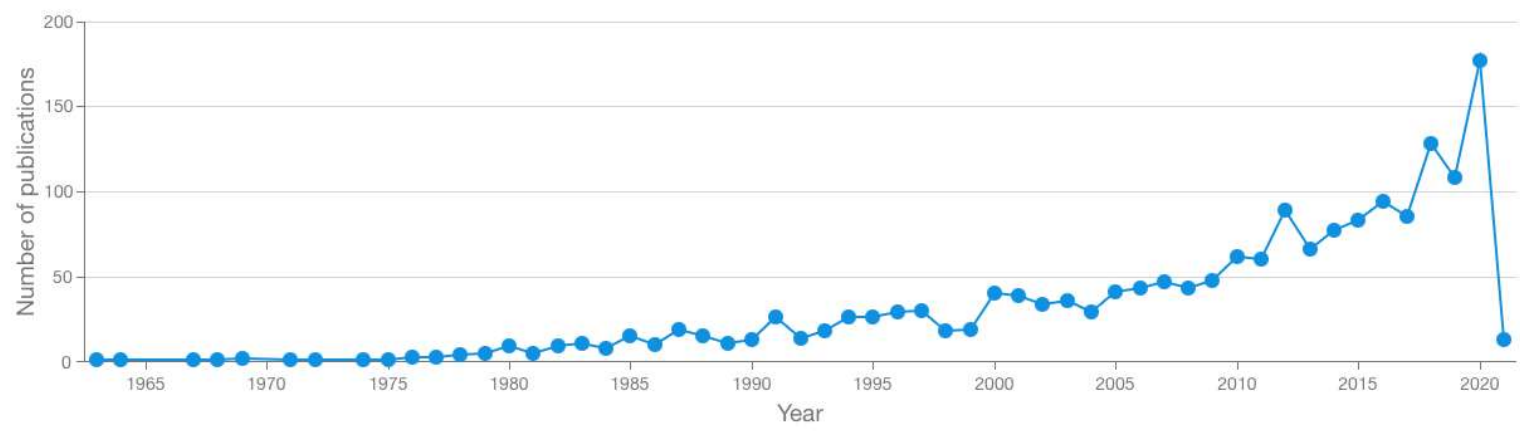

Viện Toán học là đơn vị có nhiều công bố nhất ngành Operations research, mathematical programming. Tiếp đó là Trường Đại học Quốc tế - Đại học Quốc gia TP. Hồ Chí Minh và Khoa ToánThống kê của Trường Đại học Tôn Đức Thắng (Bảng 10). Tất cả 10 cơ quan ở Bảng 10 đều ở miền Bắc và miền Nam.

Bảng 10. Các cơ sở nghiên cứu năng suất nhất ngành Operations research, mathematical programming 


\begin{tabular}{|l|r|}
\hline \multicolumn{1}{|c|}{ Cơ sở nghiên cứu } & $\begin{array}{r}\text { Số lượng } \\
\text { công bố }\end{array}$ \\
\hline Viện Toán học (Viện Hàn lâm Khoa học Công nghệ Việt Nam) & 154 \\
\hline Trường Đại học Quốc tế (Đại học Quốc gia TP. Hồ Chí Minh) & 85 \\
\hline Khoa Toán Thống Kê (Trường Đại học Tôn Đức Thắng) & 60 \\
\hline Trường Đại học Khoa học Tự nhiên (Đại học Quốc gia TP. Hồ Chí Minh) & 54 \\
\hline Khoa Sư Phạm (Trường Đại học Cần Thơ') & 40 \\
\hline Trường Đại học Sư Phạm Hà Nội 2 (Trường Đại học Sư Phạm Hà Nội) & 32 \\
\hline Khoa Cơ bản (Học viện Công nghệ Bưu chính Viễn Thông) & 31 \\
\hline Viện Toán Ứng dụng và Tin học (Đại học Bách khoa Hà Nội) & 27 \\
\hline Trường Đại học Khoa học (Đại học Thái Nguyên) & 24 \\
\hline Trường Đại học Khoa học Tự nhiên (Đại học Quốc gia Hà Nội) & 24 \\
\hline
\end{tabular}

Hiện nay, hầu hết các tác giả năng suất nhất ngành đều sinh truớc năm 1980 (Bảng 11). Ngoài ra, có một số tác giả đang công tác tại nước ngoài. Đó là Lê Thị Hoài An (Đại học Lorraine, Pháp), Phạm Đình Tảo (Viện khoa học và ứng dụng quốc gia Rouen, Pháp), Nguyễn Mậu Nam (Portland State University, Hoa Kỳ).

Bảng 11. Các tác giả có nhiều công bố nhất ngành Operations research, mathematical programming

\begin{tabular}{|l|r|r|}
\hline \multicolumn{1}{|c|}{ Tên tác giả } & Số lượng công bố & Năm xuất bản nghiên cứu đầu tiên \\
\hline Lê Thị Hoài An & 58 & 1996 \\
\hline Phan Quốc Khánh & 55 & 1979 \\
\hline Nguyễn Đông Yên & 38 & 1985 \\
\hline Phạm Đình Tảo & 35 & 1995 \\
\hline Nguyễn Mậu Nam & 35 & 2005 \\
\hline Lâm Quốc Anh & 34 & 2004 \\
\hline Phạm Ngọc Anh & 33 & 2004 \\
\hline Lê Dũng Mưu & 33 & 1978 \\
\hline Thái Doãn Chương & 29 & 2009 \\
\hline Nguyễn Định & 28 & 1992 \\
\hline
\end{tabular}

Khó có thể xác định được các nhóm nghiên cứu đông tác giả trong ngành Operations research vì kích thước đồng đều của nhiều nhóm và mối quan hệ chằng chịt giữa các nhóm (Hình 28). Ngoài ra, trong ngành dường như có mối quan hệ hợp tác lớn giữa người Việt trong và ngoài nước, giữa người Việt và người nước ngoài. Hai tác giả nước ngoài có vai trò lớn trong mạng lưới này là Boris $S$. Mordukhovich và Jen-Chih Yao. Ở Hình 28, một số tác giả có năng suất nghiên cứu cao là Lê Thị Hoài An, Phan Quốc Khánh, Nguyễn Mậu Nam và Lê Dũng Mưu được khoanh tròn và đánh số lần lượt từ 1 đến 4. Hai tác giả nước ngoài Boris $\mathrm{S}$. Mordukhovich và Jen-Chih Yao được đánh dấu bằng hình chữ nhật.

Hình 28. Mạng lưới hợp tác ngành Operations research, mathematical programming 


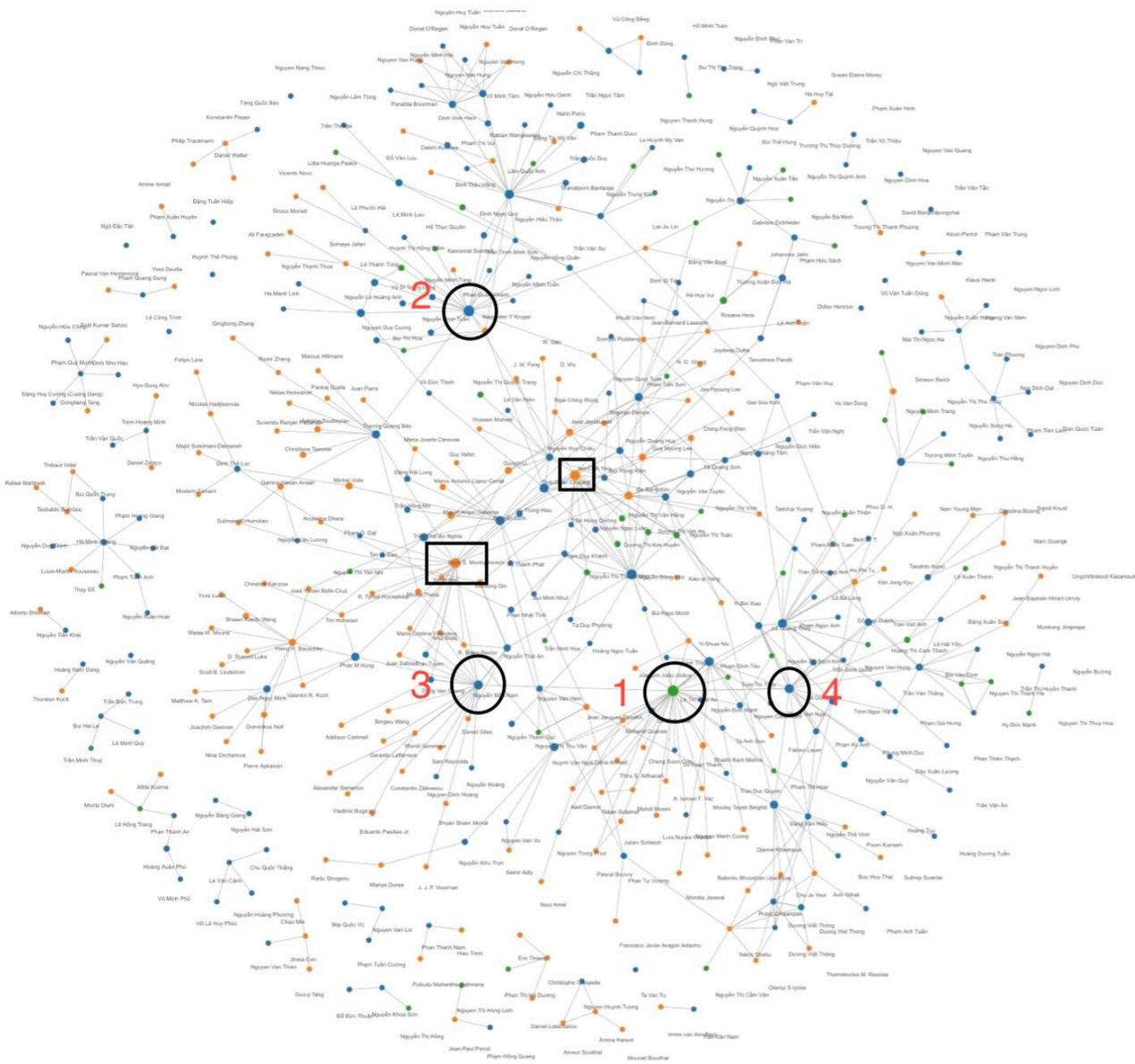

\subsection{Ngành Operator theory}

Trước 2007, số lượng bài ngành Operator theory không có nhiều biến động. Từ cuối những năm 2000, và đặc biệt sau 2010, số lượng nghiên cứu mỗi năm tăng nhanh chóng (Hình 29).

Hình 29. Năng suất nghiên cứu hằng năm ngành Operator theory

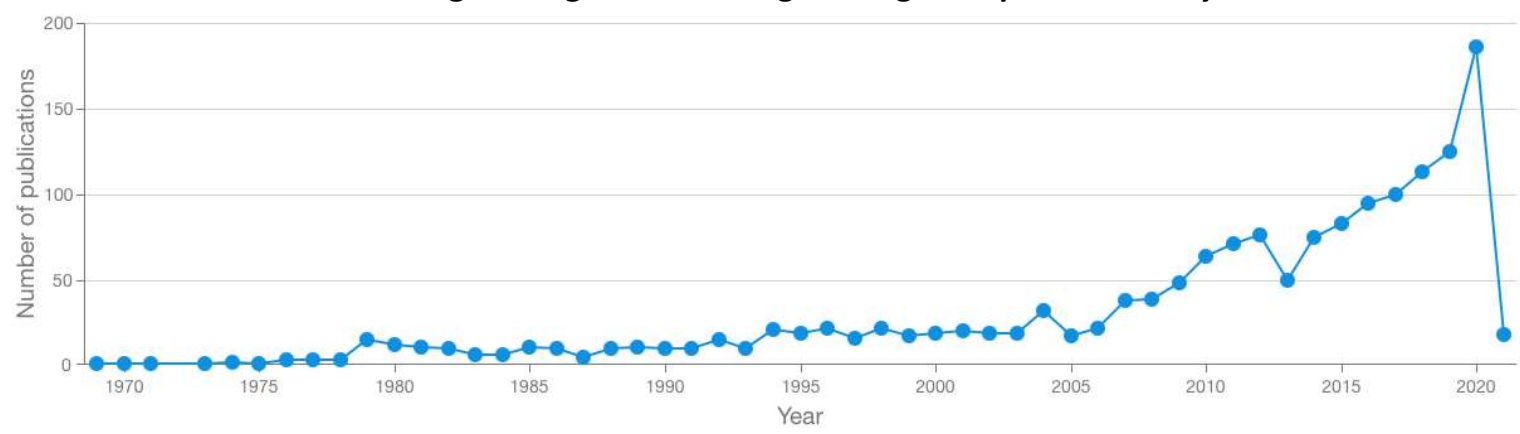

Khoa Toán-Thống kê của trường Đại học Tôn Đức Thắng là cơ quan có nhiều công bố nhất ngành Operator theory trong giai đoạn 2010-2020 (Bảng 12). Theo Bảng 13, tác giả có nhiều công bố nhất 
ngành này, Nguyễn Huy Tuấn, đang công tác tại đây. 5 trong 7 tác giả trong Bảng 13 mới bắt đầu công bố trong 15 năm gần đây.

Bảng 12. Các cơ sở nghiên cứu năng suất nhất ngành Operator theory

\begin{tabular}{|l|r|}
\hline \multicolumn{1}{|c|}{ Cơ sở nghiên cứu } & $\begin{array}{c}\text { Số lượng } \\
\text { công bố }\end{array}$ \\
\hline Khoa Toán Thống Kê (Trường Đại học Tôn Đức Thắng) & 151 \\
\hline Trường Đại học Khoa học Tự nhiên (Đại học Quốc gia TP. Hồ Chí Minh) & 79 \\
\hline Trường Đại học Khoa học Tự nhiên (Đại học Quốc gia Hà Nội) & 72 \\
\hline Viện Toán học (Viện Hàn lâm Khoa học Công nghệ Việt Nam) & 55 \\
\hline Trường Đại học Khoa học (Đại học Thái Nguyên) & 43 \\
\hline Viện Toán Ứng dụng và Tin học (Đại học Bách khoa Hà Nội) & 35 \\
\hline Khoa Toán-Tin (Trường Đại học Sư Phạm Hà Nội) & 33 \\
\hline Viện Nghiên cứu và Phát triển Công nghệ cao (Đại học Duy Tân) & 32 \\
\hline Viện Công nghệ Thông tin (Viện Hàn lâm Khoa học Công nghệ Việt Nam) & 29 \\
\hline Khoa Sư phạm Toán-Tin (Trường Đại học Đồng Tháp) & 27 \\
\hline
\end{tabular}

Bảng 13. Các tác giả có nhiều công bố nhất ngành Operator theory

\begin{tabular}{|l|r|r|}
\hline \multicolumn{1}{|c|}{ Tên tác giả } & Số công bố & Năm xuất bản nghiên cứu đầu tiên \\
\hline Nguyễn Huy Tuấn & 75 & 2006 \\
\hline Đặng Văn Hiếu & 50 & 2014 \\
\hline Dương Việt Thông & 48 & 2011 \\
\hline Nguyễn Bường & 33 & 1985 \\
\hline Lê Long Triều & 26 & 2007 \\
\hline Đặng Đức Trọng & 25 & 1994 \\
\hline Trương Minh Tuyên & 24 & 2009 \\
\hline
\end{tabular}

Mạng lưới hợp tác ngành Operator theory có nhiều nhóm nghiên cứu đông thành viên trong và ngoài nước (Hình 30). Ví dụ, nhóm của Nguyễn Huy Tuấn, Đặng Văn Hiếu và Lê Long Triều, được khoanh tròn và đánh dấu theo thứ tự 1, 2 và 3 trong Hình 30. Giữa nhóm của Nguyễn Huy Tuấn và Đặng Văn Hiếu đã có kết nối hợp tác, nhưng chưa nhiều.

Hình 30. Mạng lưới hợp tác ngành Operator theory 


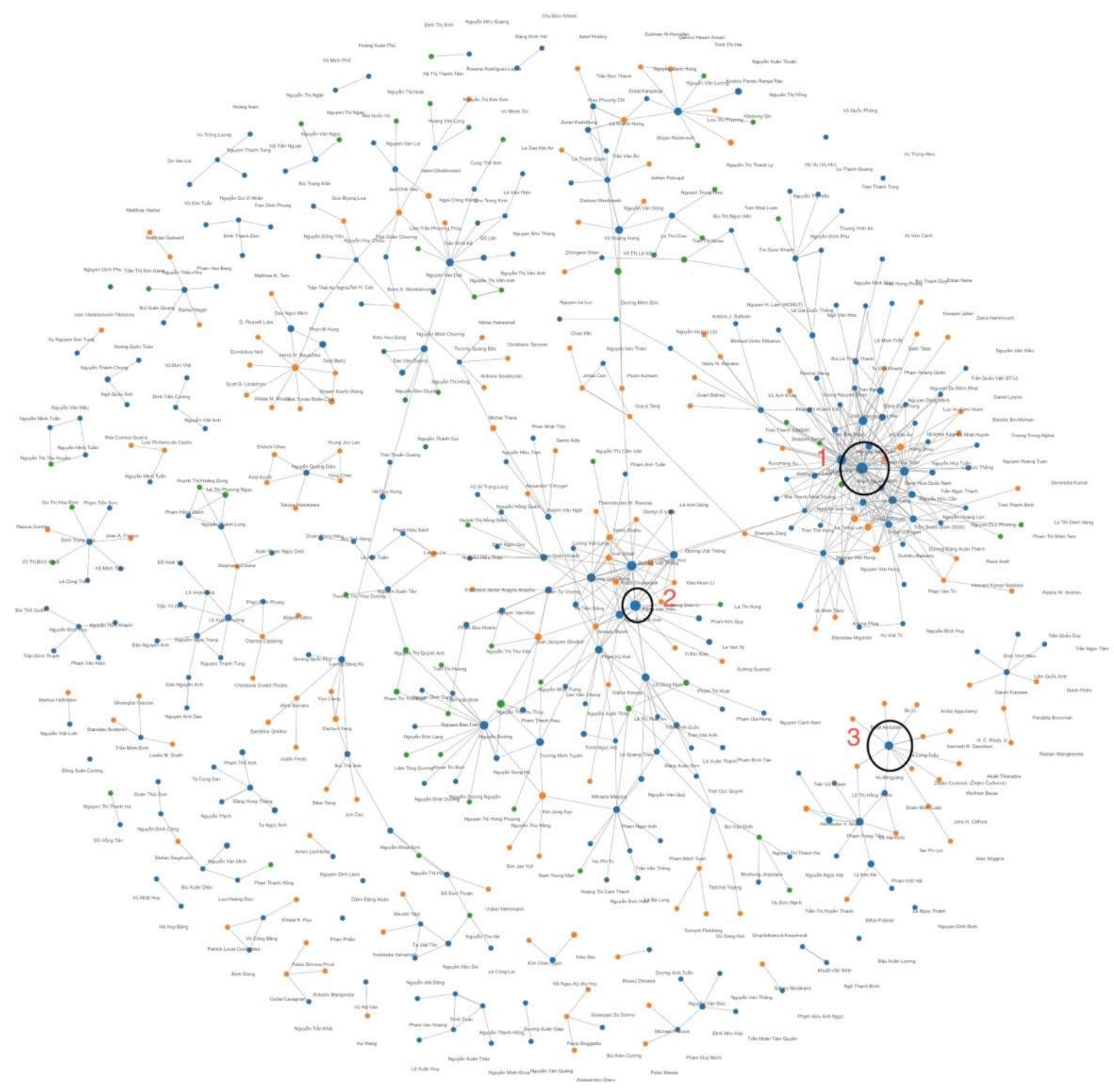

\subsection{Ngành Several complex variables and analytic spaces}

Số lượng công bố Several complex variables and analytic spaces tăng đáng kể trong 10 năm gần đây (Hình 31). Tuy nhiên, số lượng mỗi năm chỉ khoảng vài chục bài, và không ổn định.

Hình 31. Năng suất nghiên cứu hằng năm ngành Several complex variables and analytic spaces 


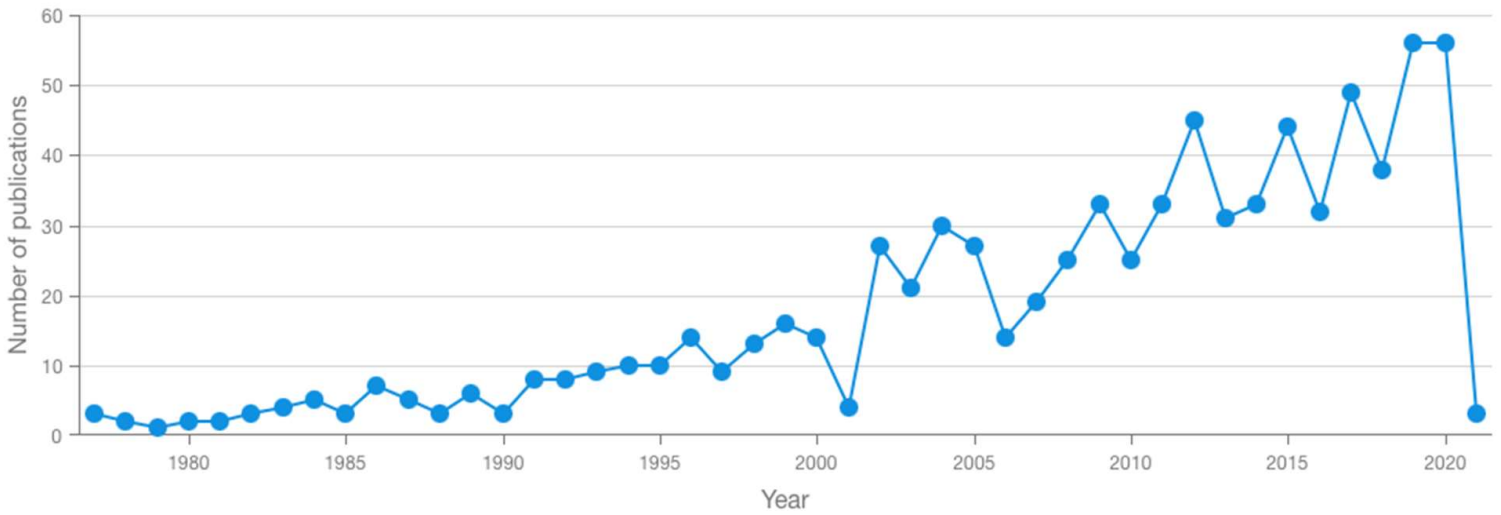

Trong giai đoạn 2010-2020, cơ quan có số lượng bài cao nhất trong ngành này là Đại học Sư phạm Hà Nội (Bảng 14). Đây là nơi học tập hoặc làm việc của 6 trên 10 tác giả năng suất nhất ngành (Sĩ Đức Quang, Nguyễn Xuân Hồng, Lê Mậu Hải, Phạm Hoàng Hiệp, Nguyễn Quang Diệu, Phạm Đức Thoan) (Bảng 15).

Bảng 14. Các cơ sở nghiên cứu năng suất nhất ngành Several complex variables and analytic spaces

\begin{tabular}{|l|r|}
\hline \multicolumn{1}{|c|}{ Cơ sở nghiên cứu } & \multicolumn{1}{|c|}{ Số công bố } \\
\hline $\begin{array}{l}\text { Khoa Toán-Tin (Trường Đại học Sư Phạm } \\
\text { Hà Nội) }\end{array}$ & 131 \\
\hline $\begin{array}{l}\text { Viện Toán học (Viện Hàn lâm Khoa học } \\
\text { Công nghệ Việt Nam) }\end{array}$ & 43 \\
\hline $\begin{array}{l}\text { Trường Đại học Khoa học Tự nhiên (Đại } \\
\text { học Quốc gia Hà Nội) }\end{array}$ & 26 \\
\hline $\begin{array}{l}\text { Viện Toán học và Khoa học Ứng dụng } \\
\text { (Trường Đại học Thăng Long) }\end{array}$ & 25 \\
\hline $\begin{array}{l}\text { Trường Đại học Khoa học Tự nhiên (Đại } \\
\text { học Quốc gia TP. Hồ Chí Minh) }\end{array}$ & 18 \\
\hline $\begin{array}{l}\text { Khoa Toán-Tin học (Trường Đại học Đà } \\
\text { Lạt) }\end{array}$ & 15 \\
\hline $\begin{array}{l}\text { Trường Đại học Sư phạm (Đại học Thái } \\
\text { Nguyên) }\end{array}$ & 11 \\
\hline $\begin{array}{l}\text { Khoa Công nghệ Thông tin (Trường Đại } \\
\text { học Xây dựng) }\end{array}$ & 8 \\
\hline $\begin{array}{l}\text { Khoa Khoa học Tự nhiên (Trường Đại học } \\
\text { Điện lực) }\end{array}$ & 7 \\
\hline Trường Đại học Sư Phạm Hà Nội & \\
\hline
\end{tabular}

Bảng 15. Các tác giả có nhiều công bố nhất ngành Several complex variables and analytic spaces

\begin{tabular}{|l|r|}
\hline \multicolumn{1}{|c|}{ Tên tác giả } & \multicolumn{1}{c|}{ Số công bố } \\
\hline Sĩ Đức Quang & 46 \\
\hline Nguyễn Xuân Hồng & 26 \\
\hline Lê Mậu Hải & 23 \\
\hline Phạm Hoàng Hiệp & 22 \\
\hline Đinh Tiến Cường & 21 \\
\hline
\end{tabular}




\begin{tabular}{|l|r|} 
Lý Kim Hà & 17 \\
\hline Lữ Hoàng Chinh & 16 \\
\hline Nguyễn Quang Diệu & 16 \\
\hline Phạm Tiến Sơn & 15 \\
\hline Phạm Đức Thoan & 15 \\
\hline
\end{tabular}

Mạng lưới hợp tác nghiên cứu ngành Several complex variables and analytic spaces (Hình 32) cho thấy mối quan hệ chặt chẽ giữa các tác giả có nhiều công bố, đặc biệt là bốn tác giả Nguyễn Xuân Hồng, Lê Mậu Hải, Phạm Hoàng Hiệp và Nguyễn Quang Diệu. Hai tác giả Lý Kim Hà và Lữ Hoàng Chinh dù chưa hợp tác với 6 người trên nhưng vẫn có quan hệ gián tiếp với nhóm. Chỉ hai tác giả Đinh Tiến Cường và Phạm Tiến Sơn là không có mối liên hệ hợp tác.

Trong hình 32, các tác giả dẫn đầu về số lượng công bố ngành Several complex variables and analytic spaces trong Bảng 15 có liên quan tới trường Đại học Sư phạm Hà Nội sẽ được khoanh tròn. Hai tác giả Lý Kim Hà và Lữ Hoàng Chinh được đánh dấu bằng hình chữ nhật. Hai tác giả Đinh Tiến Cường và Phạm Tiến Sơn được đánh dấu bằng hình sao.

Hình 32. Mạng lưới hợp tác ngành Several complex variables and analytic spaces

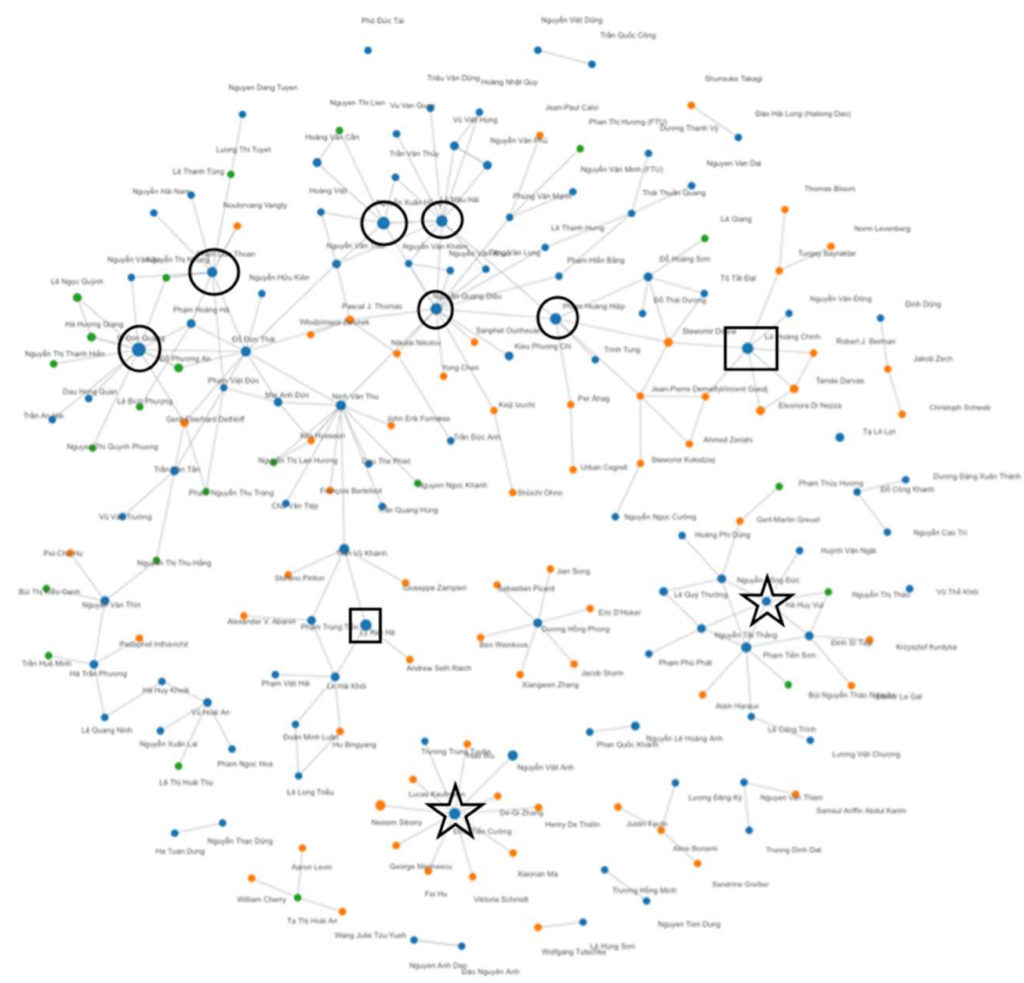

\subsection{Ngành Commutative algebra và ngành Group theory and generalizations}

Một trong các ngành toán mà người Việt có mạng lưới liên kết rộng lớn với người nước ngoài là Commutative algebra và Group theory and generalizations. Lý do có thể là một số tác giả năng suất nhất của các ngành trên đều đang làm việc ở nuớc ngoài. Dưới đây là danh sách tác giả dẫn đầu ngành Commutative algebra về số lượng công bố và hình vẽ mạng lưới hợp tác. Về các tác giả ở Việt Nam, phần lớn đang công tác tại Viện Toán học (Viện Hàn Lâm Khoa học Công nghệ Việt Nam) (Bảng 16). 
Bảng 16. 10 tác giả có số lượng công bố cao nhất ngành Commutative algebra

\begin{tabular}{|l|l|l|}
\hline \multicolumn{1}{|c|}{ Tên tác giả } & \multicolumn{1}{|c|}{ Số công bố } & \multicolumn{1}{c|}{ Nơi làm việc từ 2010 đến 2020} \\
\hline Đào Hải Long & 32 & University of Kansas, Hoa Kỳ \\
\hline Hà Huy Tài & 27 & Tulane University, \\
\hline Phạm Hùng Quý & 27 & Đại học FPT \\
\hline Ngô Việt Trung & 19 & $\begin{array}{l}\text { Viện Toán học (Viện Hàn lâm Khoa học Công } \\
\text { nghệ Việt Nam) }\end{array}$ \\
\hline Hoàng Lê Trường & 17 & $\begin{array}{l}\text { Viện Toán học (Viện Hàn lâm Khoa học Công } \\
\text { nghệ Việt Nam) }\end{array}$ \\
\hline Trần Nam Trung & 17 & $\begin{array}{l}\text { Viện Toán học (Viện Hàn lâm Khoa học Công } \\
\text { nghệ Việt Nam) }\end{array}$ \\
\hline Lê Tuấn Hoa & 16 & $\begin{array}{l}\text { Viện Toán học (Viện Hàn lâm Khoa học Công } \\
\text { nghệ Việt Nam) }\end{array}$ \\
\hline Nguyễn Đăng Hợp & $\begin{array}{l}\text { University of Osnabrueck, Đức } \\
\text { Viện Toán học (Viện Hàn lâm Khoa học Công } \\
\text { nghệ Việt Nam) } \\
\text { University of Genoa, Ý } \\
\text { Otto von Guericke University Magdeburg, Đức } \\
\text { Korean Advanced Institute of Science and } \\
\text { Technology (KAIST), Hàn Quốc }\end{array}$ \\
\hline Nguyễn Tự Cường & 14 & $\begin{array}{l}\text { Viện Toán học (Viện Hàn lâm Khoa học Công } \\
\text { nghệ Việt Nam) }\end{array}$ \\
\hline Đgại học Sư phạm Hà Nội \\
\hline
\end{tabular}

Trong mạng lưới Hình 33, hạt màu cam đại diện tác giả nam người Việt, màu xanh dương đại diện tác giả nữ người Việt, màu xanh lá đại diện người nước ngoài. Số lượng người Việt và người nước ngoài gần như ngang nhau.

Hình 33. Mạng lưới hợp tác ngành Commutative algebra tại Việt Nam 


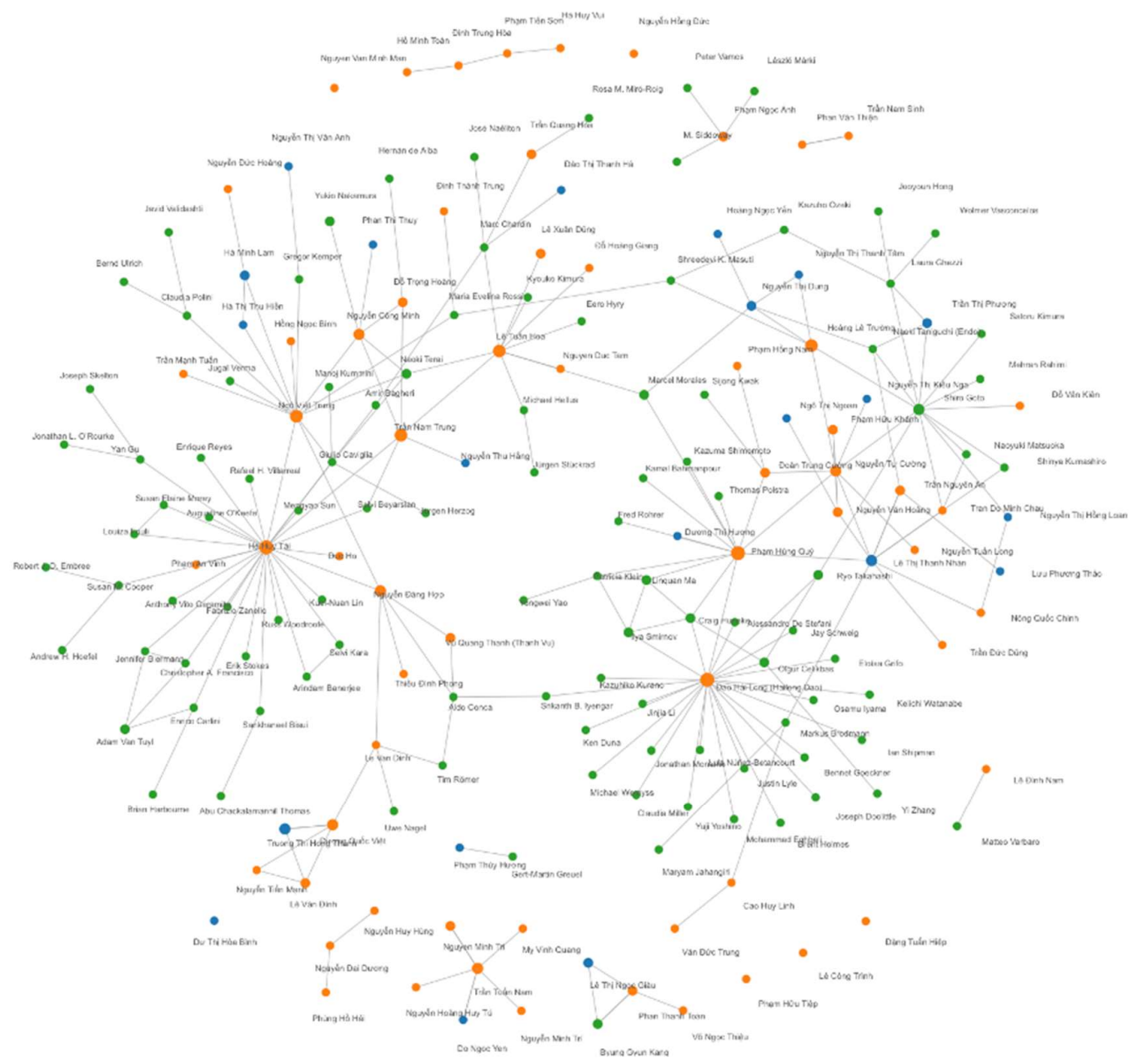

Tỷ lệ tác giả nước ngoài trong mạng lưới hợp tác ngành Group theory and generalizations còn cao hơn ngành Commutative algebra (Hình 34). Phần lớn là do mạng lưới hợp tác của ba tác giả đang công tác tại nước ngoài là Phạm Hữu Tiệp, Tống Viết Phi Hùng và Nguyễn Ngọc Hưng (Bảng 17).

Bảng 17. 10 tác giả có số lượng công bố lớn nhất ngành Group theory and generalizations

\begin{tabular}{|l|l|l|}
\hline \multicolumn{1}{|c|}{ Tên tác giả } & \multicolumn{1}{|c|}{ Số công bố } & \multicolumn{1}{c|}{ Nơi làm việc từ 2010 đến 2020 } \\
\hline Phạm Hữu Tiệp & 91 & $\begin{array}{l}\text { University of Arizona, Hoa Kỳ } \\
\text { Rutgers University, Hoa Kỳ }\end{array}$ \\
\hline Tống Viết Phi Hùng & 52 & $\begin{array}{l}\text { Universities of Pretoria và KwaZulu- } \\
\text { Natal, Nam Phi } \\
\text { Bielefeld University, Đức } \\
\text { Wayne State University, Hoa Kỳ } \\
\text { Kent State University, Hoa Kỳ } \\
\text { Binghamton University, Hoa Kỳ }\end{array}$ \\
\hline Nguyễn Ngọc Hưng & 29 & University of Akron, Hoa Kỳ \\
\hline Nguyễn Quốc Thắng & 20 & $\begin{array}{l}\text { Viện Toán học (Viện Hàn lâm Khoa học } \\
\text { Công nghệ Việt Nam) }\end{array}$ \\
\hline Nguyễn Duy Tân & 8 & University of Duisburg-Essen, Đức \\
\hline
\end{tabular}




\begin{tabular}{|l|l|l|} 
& & University of Western Ontario, Hoa Kỳ \\
\hline Đào Phương Bắc & 7 & $\begin{array}{l}\text { Trường Đại học Khoa học Tự nhiên } \\
\text { (Đại học Quốc gia Hà Nội) }\end{array}$ \\
\hline Bùi Xuân Hải & 7 & $\begin{array}{l}\text { Trường Đại hộc Khoa học Tự nhiên } \\
\text { (Đại học Quốc gia TP. Hồ Chí Minh) }\end{array}$ \\
\hline Mai Hoàng Biên & 6 & Đại Học Kiến Trúc TP. Hồ Chí Minh \\
\hline Nguyễn Tiến Quang & 5 & Trường Đại học Sư phạm Hà Nội \\
\hline Ngô Thị Ngoan & 5 & $\begin{array}{l}\text { Trường Đại học Khoa học (Đại học } \\
\text { Thái Nguyên) }\end{array}$ \\
\hline
\end{tabular}

Ở mạng lưới hợp tác ngành Group theory and generalizations, màu xanh lá thể hiện người nước ngoài. Số lượng người nước ngoài áp đảo số người Việt.

Hình 34. Mạng lưới hợp tác ngành Group theory and generalizations

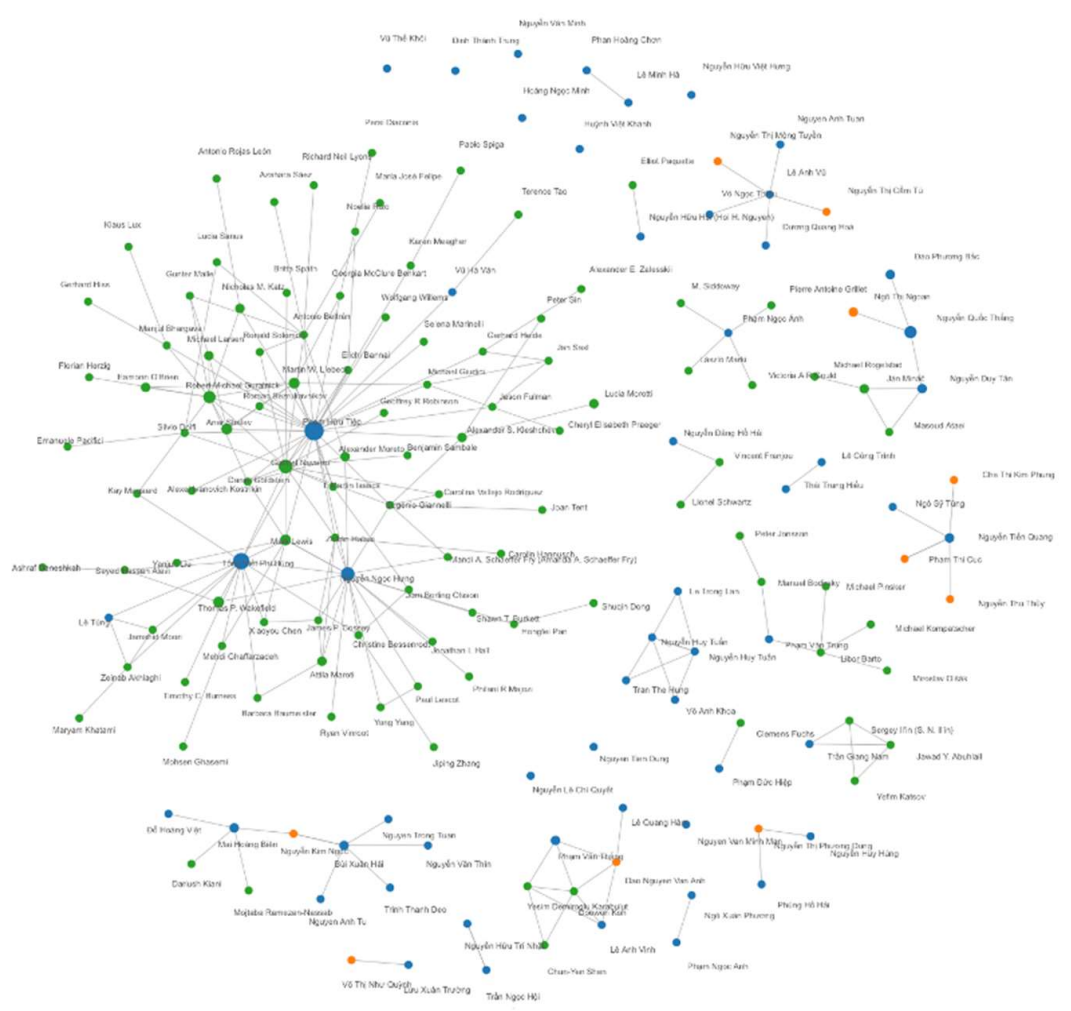

\section{Kết luận:}

Dựa vào CSDL SciMath, bản báo cáo có một số quan sát sau. Thứ nhất, số lượng công bố đã tăng mạnh. Trước năm 2010, người Việt chỉ có khoảng 200 nghiên cứu mỗi năm. Con số này đã lên đến khoảng 400 nghiên cứu/năm trong giai đoạn 2010-2018 và duy trì ở mức 600 công bố/năm trong hai năm liên tiếp 2019 và 2020. Thứ hai là những tiến bộ mới về chất lượng nghiên cứu. Trong mười năm qua, hằng năm luôn có các nghiên cứu mới đăng trên 10 tạp chí toán học hàng đầu nhưng phần lớn được thực hiện bởi các tác giả người Việt đang công tác tại nước ngoài. Dù vậy, một số tác giả trẻ công tác tại Việt Nam đã thử sức và thành công đăng nghiên cứu trên 10 tạp chí trên. Như đã đề cập từ trước, báo cáo này chưa thể nói sâu hơn về tình trạng chất lượng nghiên cứu toán học của người Việt nói chung. 
Thêm vào đó, trong giai đoạn 2010-2020, mỗi năm Việt Nam đều có thêm một lực lượng tác giả và cơ sở nghiên cứu mới gia nhập vào công tác phát triển toán học. Mạng lưới hợp tác nghiên cứu toán học cũng phát triển mạnh mẽ trong và ngoài nước. Tuy các tác giả có số lượng nghiên cứu đồ sộ thường là những người đã phát triển sự nghiệp trước những năm 2000 nhưng một số gương mặt triển vọng đã xuất hiện với năng suất và thành quả khoa học ấn tượng. Một số toán học trẻ đã xuất bản các nghiên cứu trên các tạp chí toán học hàng đầu trên thế giới như Annals of Mathematics, Duke Mathematical Journal và Advances in Mathematics. Sự gia tăng về lực lượng đội ngũ nghiên cứu, mạng lưới hợp tác và nhà nghiên cứu trẻ triển vọng hứa hẹn đột phá mới về nghiên cứu toán học trong tương lai.

Về cơ sở nghiên cứu, theo CSDL SciMath, phần lớn các cơ quan nghiên cứu dẫn đầu về năng suất đang tập trung ở các thành phố lớn như Hà Nội và TP. Hồ Chí Minh. Điều này được phản ánh bởi sự chênh lệch về năng suất và chất lượng đội ngũ giữa các tỉnh. Tuy nhiên, mạng lưới hợp tác nghiên cứu với các tỉnh và thành phố mạnh về nghiên cứu toán học có thể sẽ giúp thúc đẩy phát triển năng lực ở các tỉnh còn yếu về nghiên cứu toán, đồng thời nguồn kinh phí cũng sẽ được san sẻ đều giữa các tỉnh thành (Vuong, 2018).

Các phân ngành thu hút nhiều công bố ở Việt Nam cũng có một số thay đổi. Các ngành như Partial differential equations và Operations research, mathematical programming tăng trưởng đột biến về năng suất nghiên cứu. Tính chất của các mạng lưới hợp tác nghiên cứu cũng đa dạng về tỷ lệ giữa người Việt vàngười nước ngoài, giữa người Việt trong và ngoài nước. Ngoài ra, một số phân ngành như Partial differential equations và Operator theory xuất hiện đội ngũ nghiên cứu tương đối trẻ với năng suất dồi dào.

Như vây, đã có một số biến đổi về số lượng công bố, lực lượng tác giả tham gia nghiên cứu, xu hướng hợp tác, ... Tuy nhiên, các quan sát trên chưa đủ để kết luận về năng lực và chất lượng nghiên cứu tại Việt Nam. Vì vậy, chúng tôi đề xuất các nhà quản lý kết hợp cùng các chuyên gia trong ngành tiến hành kiểm tra, khảo sát sâu hơn về các dự án, các công bố quốc tế để có cái nhìn chuẩn xác nhất về tình hình nghiên cứu toán học của người Việt.

\section{Tài liệu tham khảo}

Chau, N.-B., et al. (2020). The 80-year development of Vietnam mathematical research: Preliminary insights from the SciMath database on mathematicians, their works and their networks. arXiv preprint arXiv:2011.09328.

Lê, T.-H. \& Trần, V.-N. (2010). Sự khởi đầu của Viện Nghiên cứu cao cấp về Toán. VIASM.URL: https://viasm.edu.vn/Cms Data/Contents/viasm/Media/file/T16S1-3-8.pdf

NAFOSTED. (n.d.). Danh mục tài trợ (List of funded projects). NAFOSTED. URL: https://nafosted.gov.vn/danh-muc-tai-tro/

Trường đại học Phenikaa. (2019). Ra mắt Trường Đại học \& Quỹ đổi mới Sáng tạo. Trường đại học Phenikaa. URL: https://phena.phenikaa-uni.edu.vn/vi/events/view/tin-tuc/su-kien/ra-mattruong-dai-hoc-quy-doi-moi-sang-tao

Thiem, L. V. (1947). Beitrag zum Typenproblem der Riemannschen Flächen. Commentarii Mathematici Helvetici, 20, 270-287.

Thủ tướng Chính phủ. (2010). Quyết định Phê duyệt "Chương trình trọng điểm quốc gia phát triển Toán học giai đoạn 2010 đến 2020". Thủ tướng Chính phủ. URL: http://www.chinhphu.vn/portal/page/portal/chinhphu/noidungchuongtrinhquocgiakhac?_p iref135_18254_135_18253_18253.strutsAction=ViewDetailAction.do\&_piref135_18254_135 _18253_18253.docid=1118\&_piref135_18254_135_18253_18253.substract $=$

VIASM (2021). Công bố. VIASM. URL: https://viasm.edu.vn/xuat-ban/cong-bo 
VINIF. (n.d.). Chương trình tài trợ Dự án Khoa học và Công nghệ. Quỹ Đổi mới sáng tạo Vingroup. URL: https://vinif.org/sponsor-programs/chuong-trinh-tai-tro-du-an-khoa-hoc-va-cong-nghe/

Vuong, Q. H. (2018). The (ir)rational consideration of the cost of science in transition economies. Nature Human Behaviour, 2(1), 5. 
Phụ lục 1. Số lượng công bố quốc tế và tác giả theo phân ngành

\begin{tabular}{|c|c|c|}
\hline Name & $\begin{array}{l}\text { Article } \\
\text { Count }\end{array}$ & $\begin{array}{l}\text { Author } \\
\text { Count }\end{array}$ \\
\hline Partial differential equations & 967 & 613 \\
\hline Numerical analysis & 527 & 523 \\
\hline Operator theory & 695 & 487 \\
\hline Operations research, mathematical programming & 754 & 442 \\
\hline Calculus of variations and optimal control; optimization & 623 & 375 \\
\hline Ordinary differential equations & 407 & 334 \\
\hline Probability theory and stochastic processes & 299 & 246 \\
\hline Systems theory; control & 228 & 206 \\
\hline Real functions & 178 & 189 \\
\hline Several complex variables and analytic spaces & 330 & 187 \\
\hline Commutative algebra & 274 & 186 \\
\hline Functional analysis & 215 & 183 \\
\hline Dynamical systems and ergodic theory & 151 & 180 \\
\hline Algebraic geometry & 188 & 170 \\
\hline Group theory and generalizations & 244 & 170 \\
\hline Combinatorics & 177 & 164 \\
\hline Game theory, economics, social and behavioral sciences & 133 & 163 \\
\hline Computer science & 111 & 156 \\
\hline Number theory & 139 & 133 \\
\hline Harmonic analysis on Euclidean spaces & 157 & 126 \\
\hline Statistics & 70 & 126 \\
\hline Associative rings and algebras & 136 & 120 \\
\hline Integral equations & 113 & 117 \\
\hline Mechanics of deformable solids & 66 & 116 \\
\hline Biology and other natural sciences & 76 & 111 \\
\hline Global analysis, analysis on manifolds & 79 & 110 \\
\hline Fluid mechanics & 89 & 103 \\
\hline Linear and multilinear algebra; matrix theory & 85 & 100 \\
\hline Functions of a complex variable & 134 & 98 \\
\hline Difference and functional equations & 93 & 89 \\
\hline Differential geometry & 84 & 83 \\
\hline General topology & 110 & 80 \\
\hline Information and communication, circuits & 47 & 74 \\
\hline Convex and discrete geometry & 58 & 69 \\
\hline Approximation and expansions & 77 & 66 \\
\hline Mathematical logic and foundations & 31 & 57 \\
\hline Integral transforms, operational calculus & 63 & 55 \\
\hline Quantum Theory & 32 & 48 \\
\hline Category theory, homological algebra & 49 & 46 \\
\hline
\end{tabular}




\begin{tabular}{|l|l|l|}
\hline Potential theory & 29 & 43 \\
\hline Optics, electromagnetic theory & 44 & 42 \\
\hline Special functions & 22 & 41 \\
\hline Classical thermodynamics, heat transfer & 20 & 40 \\
\hline Algebraic topology & 58 & 37 \\
\hline Measure and integration & 26 & 32 \\
\hline Statistical mechanics, structure of matter & 26 & 32 \\
\hline Field theory and polynomials & 28 & 31 \\
\hline Geometry & 19 & 28 \\
\hline Order, lattices, ordered algebraic structures & 21 & 27 \\
\hline General mathematics & 8 & 22 \\
\hline Topological groups, Lie groups & 12 & 21 \\
\hline Nonassociative rings and algebras & 11 & 20 \\
\hline Sequences, series, summability & 7 & 20 \\
\hline Mechanics of particles and systems & 7 & 15 \\
\hline Manifolds and cell complexes & 13 & 14 \\
\hline Abstract harmonic analysis & 6 & 14 \\
\hline General algebraic systems & 7 & 13 \\
\hline Geophysics & 3 & 13 \\
\hline K-theory & 5 & 9 \\
\hline Relativity and gravitational theory & 6 & 7 \\
\hline History and biography & 4 & 6 \\
\hline Mathematics education & 2 & 3 \\
\hline Astronomy and astrophysics & 1 & 2 \\
\hline
\end{tabular}


$\cos \cos \cos \cos c \cos \theta 000000$

\section{NHÓM DƯ ÁN SCIMATH}

Ngô Bảo Châu

Vương Quân Hoàng

Lã Việt Phương

Lê Tuấn Hoa

Lê Minh Hà

Trịnh Thị Thúy Giang

Phạm Hùng Hiệp

Nguyễn Thanh Thanh Huyền

Nguyễn Thanh Dung

Nguyễn Thị Linh

Trần Trung

Nguyễn Minh Hoàng

Hồ Mạnh Toàn

Dự án SciMath được sự hỗ trợ từ

Quỹ Đổi mới Sáng tạo Phenikaa

Chương trình Trọng điểm Quốc gia Phát triển Toán học 2010-2020 